Applied Economics

\title{
Interdependence of the banking sector and the real sector: evidence from OECD countries
}

\author{
Illkay Şendeniz-Yüncü , Levent Akdeniz \& Kürşat Aydoğan
}

To cite this article: Illkay Șendeniz-Yüncü , Levent Akdeniz \& Kürșat Aydoğan (2008)

Interdependence of the banking sector and the real sector: evidence from OECD countries, Applied Economics, 40:6, 749-764, DOI: 10.1080/00036840600735424

To link to this article: https://doi.org/10.1080/00036840600735424

$$
\text { 曲 Published online: } 11 \text { Apr } 2011 .
$$

Submit your article to this journal

Llll Article views: 66

Citing articles: 2 View citing articles $\square$




\title{
Interdependence of the banking sector and the real sector: evidence from OECD countries
}

\author{
İlkay Şendeniz-Yüncü*, Levent Akdeniz and Kürşat Aydoğan \\ Faculty of Business Administration, Bilkent University, Bilkent, 06800, \\ Ankara, Turkey
}

This article investigates the validity of the credit view hypothesis in eleven OECD (Organization for Economic Cooperation and Development) countries over the period 1987:QI to 2003:QIII. The existence of a long-run relationship between the banking sector and the real sector is supported by cointegration test results. For some of the countries in the sample, Granger causality tests show the leading role of the banking sector in the real sector, thus supporting the credit view hypothesis, whereas for other countries, the same tests indicate no interdependence.

\section{Introduction}

The relationship between the banking sector and the real sector has received considerable attention in the last two decades. Although existing literature offers ample evidence of the relationship between these two sectors, there is no consensus on the direction and strength of causal links. Clarifying the causal relationship between the banking sector and the real sector has significant policy implications. Evidence that the banking sector will affect the real sector in the long run might lead to policies that would support the banking sector in a period of falling real gross domestic product (GDP).

This study attempts to answer whether the banking sector affects the real sector, the real sector affects the banking sector, or both affect each other. More specifically, we test whether a decline in bank loan volume causes a reduction of aggregate output or whether the banking sector shrinks loans to the private sector due to an economic downturn. The credit view hypothesis asserts that the banking sector affects aggregate economic performance.
When bank health, measured by bank capital, increases, banks may be tempted to increase their loan volume; hence, investment would increase, and GDP would rise accordingly. Although there have been many studies on the credit view hypothesis, a focused interest has evolved in the last two decades, especially after the bank failures and the credit crunch in the 1980s. Towards the end of the 1980s, the USA and many other OECD (Organization for Economic Cooperation and Development) countries experienced bank failures and credit crunch. Increasing interest rates led to lower asset prices, which consequently weakened the balance sheets of firms. Loan losses and decreasing asset prices caused some banks to fail and others to sharply reduce their loan volume; therefore, the flow of credit from lenders to borrowers was interrupted, and firms that depended on banks for funds had to cut back on investments. Thus, whether the bank failures or the credit crunch deepened the economic downturns and delayed economic recovery became an interesting research question. Mainly in response to the experience of the 1980s, numerous theoretical and empirical studies investigated this question.

*Corresponding author. E-mail: sendeniz@bilkent.edu.tr 
Many studies identify a theoretical relationship between financial intermediation and the real sector, ${ }^{1}$ and the hypotheses put forth by these studies have been examined empirically. ${ }^{2}$ Among the empirical works, the US experience has received special attention. Rousseau and Wachtel (1998) examine long-run relationships for the US, the UK, Canada, Norway, and Sweden to characterize the strength and timing of links between the financial and real sectors over the $1870-1929$ period. Their results suggest a leading role for financial intermediation in real sector activity. Similarly, Thießen (2005) and Chang and Caudill (2005) find that financial development leads economic growth in two emerging markets, Russia and Taiwan. In addition, Anari et al. (2002) and Suzuki (2004) specifically examine the role of bank credit in output fluctuations and find support for the credit view hypothesis in Finland and Japan. Nevertheless, examining the relationship between the banking sector and the real sector in cross section of countries with different financial structures may help in understanding the underlying dynamics of this relationship. However, analyzing such dynamics is beyond the scope of this study.

Because the relationship between the banking sector and the real sector may differ between industrialized and developing economies, this study models the long-run relationship in eleven OECD countries over the period 1987:QI to 2003:QIII. We used time-series methods rather than crosssectional regressions because the latter cannot give country-specific details. Even within a homogenous group of countries, there may be a complex picture that cannot be unveiled by cross-sectional analysis. Time-series methodology accounts for the specificity of an individual country and provides more conclusive results than would cross-sectional studies. Time-series methods provide a better understanding of causal relationships and their evolution over time.

Throughout the study, the following time-series methods are used: unit root tests for testing the stationarity of data, cointegration tests to see the co-movement of variables and to select a vector error correction model (VECM), causality tests to analyze the strength and direction of causalities, variance decompositions to break down the variance of the forecast error for each variable into components, and impulse-response functions for impact analysis. We find cointegrating relationships between the banking sectors and the real sectors for the countries in our sample. Granger causality test results indicate that the banking sector Granger-causes the real sector in France, Germany, Korea and the Netherlands. Both the variance decomposition and impulse-response function analyses provide support for the hypothesis that the banking sector affects the real sector in Finland, Germany, Korea, the Netherlands, Portugal and Spain.

The organization of the rest of the article is as follows. Section II describes the data and diagnostic measures; Section III presents the vector error correction models. In Section IV, the variance decomposition and the impulse-response function analyses are performed. Section V concludes the article.

\section{Data and the Diagnostics}

\section{Data}

In evaluating the interdependence of the banking sector and the real sector, bank capital (BC) is used as a measure of the total equity of commercial banks in a country. The measure, total loans to the private sector (LOAN), is employed to represent the value of credit given by commercial banks to the private sector. It excludes loans made to the public sector and cross claims of one group of banks on another. Gross domestic product (GDP) is used as a real-sector performance measure. The data used for the estimations consist of quarterly observations over the period 1987:QI to 2003:QIII for eleven OECD countries, namely: Austria, Finland, France, Germany, Italy, Korea, Mexico, the Netherlands, Portugal, Spain and Turkey. The source of the data is the International Financial Statistics (IFS) Online Service of the International Monetary Fund. BC data are from the capital accounts section, and LOAN data are from the claims on the private sector section of the IFS data set. Data have been adjusted for seasonality, and natural log transformation has been applied prior to analyses.

Summary statistics for the data are given in Table 1. The reported figures are the average values of annual ratios over the analysis period of 1987 to 2002. We have excluded 2003, as we have data for only three quarters for that year.

\footnotetext{
${ }^{1}$ See Diamond (1984), Bernanke and Gertler (1987), Williamson (1987), Holmstrom and Tirole (1997), Chen (2001) and Levine (2005).

${ }^{2}$ See Lown (1988, 1990), Fackler (1990), Gunther and Moore (1993), Thornton (1994), Gunther et al. (1995), Jeong et al. (2003), Bates (2005) and Shan (2005).
} 
Table 1. Summary statistics

\begin{tabular}{lllll}
\hline Country & LOAN/GDP & ASSET/GDP & LOAN/ASSET & BC/GDP \\
\hline Austria & 0.96 & 1.66 & 0.58 & 0.11 \\
Finland & 0.69 & 0.98 & 0.70 & 0.07 \\
France & 0.89 & 1.45 & 0.61 & 0.16 \\
Germany & 1.05 & 1.63 & 0.64 & 0.12 \\
Italy & 0.62 & 0.98 & 0.63 & 0.11 \\
Korea & 0.64 & 0.76 & 0.84 & 0.06 \\
Mexico & 0.05 & 0.11 & 0.45 & 0.00 \\
Netherlands & 1.01 & 1.75 & 0.58 & 0.10 \\
Portugal & 0.84 & 1.40 & 0.60 & 0.16 \\
Spain & 0.84 & 1.31 & 0.64 & 0.15 \\
Turkey & 0.18 & 0.46 & 0.39 & 0.06 \\
\hline
\end{tabular}

Notes: (1) All ratios are the average values of annual ratios over the period 1987-2002. We have excluded 2003, as we have data for only three quarters of the year.

(2) BC: Bank capital.

(3) LOAN: Loans to private sector.

(4) GDP: Gross domestic product.

(5) ASSET: Banking sector's total assets.

The banking sector's asset-to-GDP ratio measures the size of the banking sector relative to total output. All countries in our sample exhibit asset-to-GDP ratios close to one or above, except for Mexico and Turkey. Also, the relative importance of loans within the total assets of the banking system may play an important role in interpreting the results of the analysis. In this respect, although Korea has a small banking system compared to its GDP, loans comprise $84 \%$ of the total assets of its banking sector, whereas the share of loans in total assets is low in Mexico and Turkey, countries with smaller banking systems.

\section{Diagnostics}

Unit root tests. A cointegrating relationship exists between nonstationary series, if there is a stationary linear combination between them. Therefore, one needs to test the stationarity of the series first. Augmented Dickey-Fuller (ADF) and PhillipsPerron (PP) tests are used to determine whether or not the series are stationary. The ADF and PP tests have the null hypothesis of existence of a unit root, rejection of which indicates stationarity. Table 2 presents the results for the unit root tests for bank capital, loans to the private sector and GDP for eleven countries in levels and first differences. ${ }^{3}$

At least one test failed to reject the null hypothesis at the 5 percent significance level for BC, LOAN and GDP in log levels, indicating nonstationarity, and at least one test rejected the null hypothesis for each series in $\log$ differences. For example, whereas the PP test suggested the stationarity of the first differenced LOAN series for Italy, the ADF test statistics failed to confirm stationarity for the first differenced LOAN series. Although at least one test confirmed the stationarity of the first differenced series, a Kwiatkowski-PhillipsSchmidt-Shin (KPSS, 1992) test was also performed for the series that showed inconsistency between the ADF and PP tests. We observed that KPSS test results confirmed stationarity of the first differenced series.

Cointegration tests. Existence of unit root in many time series urged the growth of the theory of nonstationary time-series analysis. Engle and Granger (1987) indicated that a linear combination of two or more nonstationary series may be stationary. If such a stationary linear combination exists, the nonstationary time series are said to be cointegrated. The stationary linear combination, which is called the cointegrating equation, is interpreted as a long-run equilibrium relationship among the variables.

We examine a common trend in the variables after failing to reject the unit root hypothesis for all series in $\log$ levels. As the unit root tests show, differencing eliminates time trends in variables and therefore yields stationarity. This stationarity allows us to analyze the short-run dynamics of these variables. However, by differencing, we ignore potential

${ }^{3}$ Lags between 1 and 20 were checked, and the lag that minimized the Akaike Information Criterion (AIC) was chosen when performing the ADF test. The Newey-West bandwidth automatic selection was used when performing the PP unit root test. 
Table 2. Unit root tests

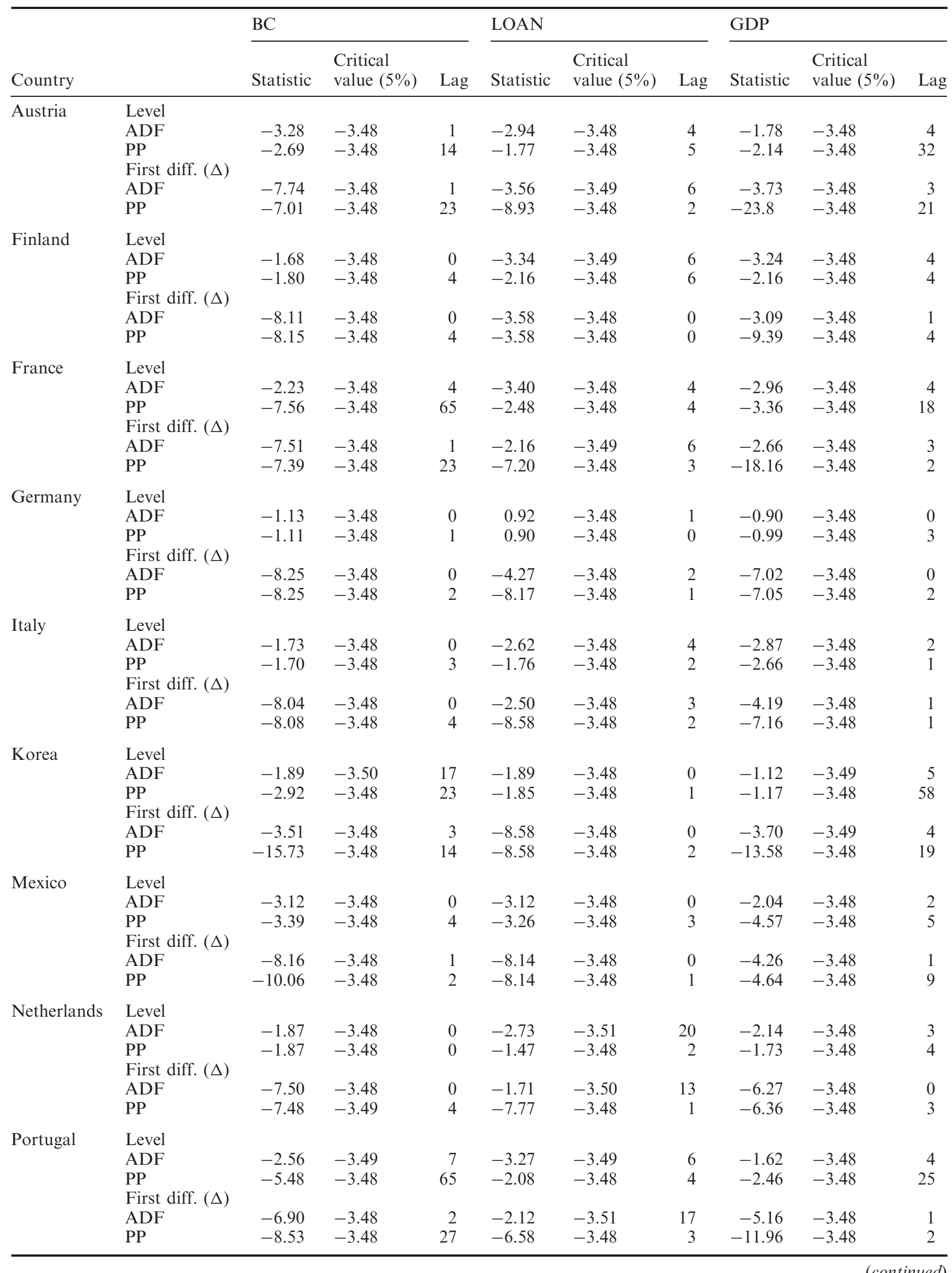


Table 2. Continued

\begin{tabular}{|c|c|c|c|c|c|c|c|c|c|c|}
\hline \multirow[b]{2}{*}{ Country } & & \multicolumn{3}{|l|}{$\mathrm{BC}$} & \multicolumn{3}{|l|}{ LOAN } & \multicolumn{3}{|l|}{ GDP } \\
\hline & & Statistic & $\begin{array}{l}\text { Critical } \\
\text { value }(5 \%)\end{array}$ & Lag & Statistic & $\begin{array}{l}\text { Critical } \\
\text { value }(5 \%)\end{array}$ & Lag & Statistic & $\begin{array}{l}\text { Critical } \\
\text { value }(5 \%)\end{array}$ & Lag \\
\hline \multirow[t]{6}{*}{ Spain } & Level & & & & & & & & & \\
\hline & $\mathrm{ADF}$ & -3.43 & -3.48 & 1 & -2.73 & -3.48 & 4 & -3.05 & -3.48 & 4 \\
\hline & $\mathrm{PP}$ & -3.01 & -3.48 & 1 & -1.64 & -3.48 & 5 & -5.34 & -3.48 & 34 \\
\hline & First diff. $(\Delta)$ & & & & & & & & & \\
\hline & $\mathrm{ADF}$ & -5.48 & -3.49 & 1 & -3.32 & -3.48 & 10 & -2.41 & -3.49 & 4 \\
\hline & PP & -6.46 & -3.48 & 1 & -8.26 & -3.48 & 5 & -11.91 & -3.48 & 8 \\
\hline \multirow[t]{6}{*}{ Turkey } & Level & & & & & & & & & \\
\hline & $\mathrm{ADF}$ & -2.82 & -3.48 & 0 & -0.97 & -3.48 & 5 & 0.84 & -3.48 & 0 \\
\hline & $\mathrm{PP}$ & -2.60 & -3.48 & 4 & -0.28 & -3.48 & 4 & 0.98 & -3.48 & 1 \\
\hline & First diff. $(\Delta)$ & & & & & & & & & \\
\hline & $\mathrm{ADF}$ & -6.60 & -3.48 & 2 & -2.38 & -3.48 & 4 & -7.94 & -3.48 & 0 \\
\hline & PP & -11.72 & -3.48 & 26 & -5.76 & -3.48 & 0 & -7.95 & -3.48 & 2 \\
\hline
\end{tabular}

Notes: (1) Data: Quarterly log data are used.

(2) BC: Bank capital.

(3) LOAN: Loans to private sector.

(4) GDP: Gross domestic product.

(5) ADF: Augmented Dickey-Fuller test ( $H_{0}$ : there is unit root). See Dickey and Fuller (1979).

(6) PP: Phillips-Perron Test ( $H_{0}$ : there is unit root). See Phillips and Perron (1988).

(7) Lags: Lags between 1 and 20 are tried, the lag that minimizes the Akaike Information Criterion (AIC) is chosen.

(8) First diff. $(\Delta)$ : the first difference operator or the change in the variable.

(9) If test statistic $>$ critical value, then $H_{0}$ is rejected.

valuable information about the long-run relationship among the variables. Although individual series are nonstationary, a linear combination of these series may be stationary. The theory of cointegration addresses the issue of integrating the short-run dynamics with the long-run equilibrium. Therefore, we searched for such a stationary linear combination - in other words, the cointegrating equation. We performed a Johansen cointegration test to see whether the nonstationary BC, LOAN and GDP move together over time and whether cointegration exists among them. The Johansen cointegration test has a null hypothesis of 'no cointegration'. Rejection of the null hypothesis indicates the existence of at least one cointegrating equation.

Table 3 presents the results of the Johansen cointegration test. The finding of cointegration between BC, LOAN and GDP at the 5 percent significance level for all countries suggests the presence of co-movements among the variables, indicating long-run stationarity. To see the speed of adjustments of the variables to deviations from their common stochastic trend, the error correction model (ECM) should be used. ECM corrects the deviation from the long-run equilibrium by short-run adjustments.

Granger causality tests. Granger causality establishes the leading role of one variable in the fluctuations of another. We perform Granger causality tests to investigate the strength and the direction of the causal link between BC, LOAN and GDP. The basic rationale of Granger causality is that change in BC Granger-causes change in LOAN, if past values of the change in $\mathrm{BC}$ improve unbiased least-squares predictions about the change in LOAN. We run Granger causality regressions of the following form:

$$
\begin{aligned}
& \Delta \mathrm{LOAN}_{t}= \sum_{i=1}^{n} \pi_{11} \Delta \mathrm{LOAN}_{t-i} \\
&+\sum_{i=1}^{n} \pi_{12} \Delta \mathrm{BC}_{t-i}+u_{t} \\
& \Delta \mathrm{BC}_{t}=\sum_{i=1}^{n} \pi_{22} \Delta \mathrm{BC}_{t-i}+\sum_{i=1}^{n} \pi_{21} \Delta \mathrm{LOAN}_{t-i}+v_{t} \\
& \Delta \mathrm{GDP}_{t}= \sum_{i=1}^{n} \phi_{11} \Delta \mathrm{GDP}_{t-i} \\
&+ \sum_{i=1}^{n} \phi_{12} \Delta \mathrm{LOAN}_{t-i}+\varepsilon_{t} \\
& \Delta \mathrm{LOAN}_{t}= \sum_{i=1}^{n} \phi_{22} \Delta \mathrm{LOAN}_{t-i} \\
&+\sum_{i=1}^{n} \phi_{21} \Delta \mathrm{GDP}_{t-i}+\eta_{t}
\end{aligned}
$$


Table 3. Johansen cointegration tests

\begin{tabular}{|c|c|c|c|}
\hline Country & Eigenvalue & $\begin{array}{l}\text { Likelihood } \\
\text { ratio }\left(Q_{\max }\right)\end{array}$ & $\begin{array}{l}\text { Critical } \\
\text { value }(5 \%)\end{array}$ \\
\hline Austria & $\begin{array}{l}0.33 \\
0.12 \\
0.02\end{array}$ & $\begin{array}{r}30.16 \\
8.51 \\
1.34\end{array}$ & $\begin{array}{r}29.68 \\
15.41 \\
3.76\end{array}$ \\
\hline Finland & $\begin{array}{l}0.36 \\
0.14 \\
0.03\end{array}$ & $\begin{array}{r}38.26 \\
10.95 \\
1.91\end{array}$ & $\begin{array}{r}29.68 \\
15.41 \\
3.76\end{array}$ \\
\hline France & $\begin{array}{l}0.40 \\
0.15 \\
0.06\end{array}$ & $\begin{array}{r}40.54 \\
12.34 \\
3.44\end{array}$ & $\begin{array}{r}29.68 \\
15.41 \\
3.76\end{array}$ \\
\hline Germany & $\begin{array}{l}0.30 \\
0.16 \\
0.14\end{array}$ & $\begin{array}{r}42.46 \\
19.95 \\
9.17\end{array}$ & $\begin{array}{r}29.68 \\
15.41 \\
3.76\end{array}$ \\
\hline Italy & $\begin{array}{l}0.50 \\
0.18 \\
0.02\end{array}$ & $\begin{array}{r}52.32 \\
12.85 \\
1.37\end{array}$ & $\begin{array}{r}29.68 \\
15.41 \\
3.76\end{array}$ \\
\hline Korea & $\begin{array}{l}0.43 \\
0.11 \\
0.00\end{array}$ & $\begin{array}{r}42.29 \\
7.65 \\
0.17\end{array}$ & $\begin{array}{r}29.68 \\
15.41 \\
3.76\end{array}$ \\
\hline Mexico & $\begin{array}{l}0.42 \\
0.14 \\
0.78\end{array}$ & $\begin{array}{r}37.98 \\
11.53 \\
3.99\end{array}$ & $\begin{array}{r}29.68 \\
15.41 \\
3.76\end{array}$ \\
\hline Netherlands & $\begin{array}{l}0.41 \\
0.19 \\
0.08\end{array}$ & $\begin{array}{r}39.25 \\
14.20 \\
4.11\end{array}$ & $\begin{array}{r}29.68 \\
15.41 \\
3.76\end{array}$ \\
\hline Portugal & $\begin{array}{l}0.28 \\
0.24 \\
0.04\end{array}$ & $\begin{array}{r}40.36 \\
19.60 \\
2.40\end{array}$ & $\begin{array}{r}29.68 \\
15.41 \\
3.76\end{array}$ \\
\hline Spain & $\begin{array}{l}0.26 \\
0.23 \\
0.03\end{array}$ & $\begin{array}{r}36.58 \\
17.68 \\
1.85\end{array}$ & $\begin{array}{r}29.68 \\
15.41 \\
3.76\end{array}$ \\
\hline Turkey & $\begin{array}{l}0.24 \\
0.17 \\
0.04\end{array}$ & $\begin{array}{r}31.35 \\
14.37 \\
2.68\end{array}$ & $\begin{array}{r}29.68 \\
15.41 \\
3.76\end{array}$ \\
\hline
\end{tabular}

Notes: (1) Series: Bank capital (BC), loans to private sector (LOAN), gross domestic product (GDP).

(2) Data: Quarterly data are used.

(3) Likelihood ratio in the third column is the maximum eigenvalues statistic $\left(Q_{\max }\right)$.

(4) First row: First row tests the hypothesis of no cointegration.

(5) Second row: Second row tests the hypothesis of at most one cointegrating equation.

(6) Third row: Third row tests the hypothesis of at most two cointegrating equations.

(7) If likelihood ratio $>$ critical value, then $H_{0}$ : no cointegration is rejected.

(8) Null hypothesis of no cointegration is rejected at the $5 \%$ significance level for the eleven countries, as the likelihood ratio test statistic values are greater than the critical values, suggesting that there exist long-run co-movements among BC, LOAN and GDP.

(9) EViews software version 4.1 is used.

(10) For detailed description of the test see Johansen (1991, 1995). where $\Delta$ is the change operator, and $u, v, \varepsilon$ and $\eta$ are the error terms. For the right-hand side of the above equations, we tried lags between 1 and 20 and chose the lag that yielded the smallest Akaike Information Criterion (AIC). ${ }^{4}$

In the above Granger causality regressions, if $\pi_{12}$ parameters are jointly zero, it indicates that change in $\mathrm{BC}$ does not Granger-cause change in LOAN; if $\pi_{21}$ parameters are jointly zero, it indicates that change in LOAN does not Granger-cause change in BC; if $\phi_{12}$ parameters are jointly zero, it indicates that change in LOAN does not Granger-cause change in GDP and if $\phi_{21}$ parameters are jointly zero, it indicates that change in GDP does not Granger-cause change in LOAN. The null hypotheses are:

(i) change in $\mathrm{BC}$ does not Granger-cause change in LOAN, in the first regression,

(ii) change in LOAN does not Granger-cause change in $\mathrm{BC}$, in the second regression,

(iii) change in LOAN does not Granger-cause change in GDP, in the third regression,

(iv) change in GDP does not Granger-cause change in LOAN, in the fourth regression.

Table 4 presents the results of Granger causality tests. We observed that in Germany and Korea, change in BC Granger-causes change in LOAN, and change in LOAN Granger-causes change in GDP $(\Delta \mathrm{BC} \Rightarrow \Delta \mathrm{LOAN} \Rightarrow \Delta \mathrm{GDP})$. We observed the reverse causality in France and Turkey; that is, change in GDP Granger-causes change in LOAN and change in LOAN Granger-causes change in $\mathrm{BC}$ $(\Delta \mathrm{GDP} \Rightarrow \Delta \mathrm{LOAN} \Rightarrow \Delta \mathrm{BC})$.

The credit view suggests that an increase in bank loans has a strong effect on GDP expenditures and economic activity. For France, Germany, Korea and the Netherlands, we found that change in LOAN Granger-causes change in GDP $(\Delta \mathrm{LOAN} \Rightarrow \Delta \mathrm{GDP})$. The causalities are observed with a 1 percent significance level for France, Germany and Korea and with a 5 percent significance level for the Netherlands. We did not observe this relationship for the other countries.

Examining the reverse causation, test results show that for France, change in GDP Granger-causes change in LOAN with a 1 percent significance level, and for Turkey, change in GDP Granger-causes change in LOAN with a 10 percent significance level $(\Delta \mathrm{GDP} \Rightarrow \Delta \mathrm{LOAN})$. There is bi-directional causality

\footnotetext{
${ }^{4}$ The Schwarz Criterion (SC) is also used in conjunction with AIC for the sake of confirmation. No contradiction is observed between AIC and SC; both point to the same lag choices.
} 
Table 4. Granger causality tests

\begin{tabular}{|c|c|c|c|c|}
\hline Country & $\begin{array}{l}\text { Variable and } \\
\text { direction }\end{array}$ & Probability & AIC & Lag \\
\hline \multirow[t]{4}{*}{ Austria } & $\Delta \mathrm{BC} \Rightarrow \Delta \mathrm{LOAN}$ & $0.03 * *$ & -10.76 & 4 \\
\hline & $\Delta \mathrm{LOAN} \Rightarrow \Delta \mathrm{BC}$ & 0.92 & -10.76 & 4 \\
\hline & $\Delta \mathrm{LOAN} \Rightarrow \Delta \mathrm{GDP}$ & 0.16 & -12.29 & 4 \\
\hline & $\Delta \mathrm{GDP} \Rightarrow \Delta \mathrm{LOAN}$ & 0.34 & -12.29 & 4 \\
\hline \multirow[t]{4}{*}{ Finland } & $\Delta \mathrm{BC} \Rightarrow \Delta \mathrm{LOAN}$ & 0.30 & -6.17 & 4 \\
\hline & $\Delta \mathrm{LOAN} \Rightarrow \Delta \mathrm{BC}$ & $0.09 *$ & -6.17 & 4 \\
\hline & $\Delta \mathrm{LOAN} \Rightarrow \Delta \mathrm{GDP}$ & 0.34 & -10.23 & 4 \\
\hline & $\Delta \mathrm{GDP} \Rightarrow \Delta \mathrm{LOAN}$ & 0.11 & -10.23 & 4 \\
\hline \multirow[t]{4}{*}{ France } & $\Delta \mathrm{BC} \Rightarrow \Delta \mathrm{LOAN}$ & 0.76 & -9.74 & 5 \\
\hline & $\Delta \mathrm{LOAN} \Rightarrow \Delta \mathrm{BC}$ & $0.01 * * *$ & -9.74 & 5 \\
\hline & $\Delta \mathrm{LOAN} \Rightarrow \Delta \mathrm{GDP}$ & $0.01 * * *$ & -12.01 & 4 \\
\hline & $\Delta \mathrm{GDP} \Rightarrow \Delta \mathrm{LOAN}$ & $0.01 * * *$ & -12.01 & 4 \\
\hline \multirow[t]{4}{*}{ Germany } & $\Delta \mathrm{BC} \Rightarrow \Delta \mathrm{LOAN}$ & $0.03 * *$ & -9.00 & 4 \\
\hline & $\Delta \mathrm{LOAN} \Rightarrow \Delta \mathrm{BC}$ & 0.61 & -9.00 & 4 \\
\hline & $\Delta \mathrm{LOAN} \Rightarrow \Delta \mathrm{GDP}$ & $0.00 * * *$ & -10.84 & 4 \\
\hline & $\Delta \mathrm{GDP} \Rightarrow \Delta \mathrm{LOAN}$ & 0.57 & -10.84 & 4 \\
\hline \multirow[t]{4}{*}{ Italy } & $\Delta \mathrm{BC} \Rightarrow \Delta \mathrm{LOAN}$ & 0.35 & -8.69 & 11 \\
\hline & $\Delta \mathrm{LOAN} \Rightarrow \Delta \mathrm{BC}$ & 0.92 & -8.69 & 11 \\
\hline & $\Delta \mathrm{LOAN} \Rightarrow \Delta \mathrm{GDP}$ & 0.74 & -9.75 & 4 \\
\hline & $\Delta \mathrm{GDP} \Rightarrow \Delta \mathrm{LOAN}$ & 0.38 & -9.75 & 4 \\
\hline \multirow[t]{4}{*}{ Korea } & $\Delta \mathrm{BC} \Rightarrow \Delta \mathrm{LOAN}$ & $0.02 * *$ & -9.74 & 5 \\
\hline & $\Delta \mathrm{LOAN} \Rightarrow \Delta \mathrm{BC}$ & $0.08 *$ & -9.74 & 5 \\
\hline & $\Delta \mathrm{LOAN} \Rightarrow \Delta \mathrm{GDP}$ & $0.01 * * *$ & -11.31 & 8 \\
\hline & $\Delta \mathrm{GDP} \Rightarrow \Delta \mathrm{LOAN}$ & 0.27 & -11.31 & 8 \\
\hline \multirow[t]{4}{*}{ Mexico } & $\Delta \mathrm{BC} \Rightarrow \Delta \mathrm{LOAN}$ & $0.02 * *$ & -0.68 & 4 \\
\hline & $\Delta \mathrm{LOAN} \Rightarrow \Delta \mathrm{BC}$ & $0.08^{*}$ & -0.68 & 4 \\
\hline & $\Delta \mathrm{LOAN} \Rightarrow \Delta \mathrm{GDP}$ & 0.64 & -6.17 & 4 \\
\hline & $\Delta \mathrm{GDP} \Rightarrow \Delta \mathrm{LOAN}$ & 0.29 & -6.17 & 4 \\
\hline \multirow[t]{4}{*}{ Netherlands } & $\Delta \mathrm{BC} \Rightarrow \Delta \mathrm{LOAN}$ & 0.54 & -9.10 & 7 \\
\hline & $\Delta \mathrm{LOAN} \Rightarrow \Delta \mathrm{BC}$ & 0.69 & -9.10 & 7 \\
\hline & $\Delta \mathrm{LOAN} \Rightarrow \Delta \mathrm{GDP}$ & $0.05 * *$ & -12.03 & 8 \\
\hline & $\Delta \mathrm{GDP} \Rightarrow \Delta \mathrm{LOAN}$ & 0.20 & -12.03 & 8 \\
\hline \multirow[t]{4}{*}{ Portugal } & $\Delta \mathrm{BC} \Rightarrow \Delta \mathrm{LOAN}$ & 0.32 & -6.97 & 4 \\
\hline & $\Delta \mathrm{LOAN} \Rightarrow \Delta \mathrm{BC}$ & 0.69 & -6.97 & 4 \\
\hline & $\Delta \mathrm{LOAN} \Rightarrow \Delta \mathrm{GDP}$ & 0.66 & -9.72 & 4 \\
\hline & $\Delta \mathrm{GDP} \Rightarrow \Delta \mathrm{LOAN}$ & 0.73 & -9.72 & 4 \\
\hline \multirow[t]{4}{*}{ Spain } & $\Delta \mathrm{BC} \Rightarrow \Delta \mathrm{LOAN}$ & 0.18 & -10.05 & 4 \\
\hline & $\Delta \mathrm{LOAN} \Rightarrow \Delta \mathrm{BC}$ & $0.06^{*}$ & -10.05 & 4 \\
\hline & $\Delta \mathrm{LOAN} \Rightarrow \Delta \mathrm{GDP}$ & 0.58 & -11.02 & 4 \\
\hline & $\Delta \mathrm{GDP} \Rightarrow \Delta \mathrm{LOAN}$ & 0.26 & -11.02 & 4 \\
\hline \multirow[t]{4}{*}{ Turkey } & $\Delta \mathrm{BC} \Rightarrow \Delta \mathrm{LOAN}$ & 0.23 & -2.90 & 5 \\
\hline & $\Delta \mathrm{LOAN} \Rightarrow \Delta \mathrm{BC}$ & $0.01 * * *$ & -2.90 & 5 \\
\hline & $\Delta \mathrm{LOAN} \Rightarrow \Delta \mathrm{GDP}$ & 0.11 & -4.72 & 5 \\
\hline & $\Delta \mathrm{GDP} \Rightarrow \Delta \mathrm{LOAN}$ & $0.06^{*}$ & -4.72 & 5 \\
\hline
\end{tabular}

Notes: (1) Data: Quarterly first difference data are used.

(2) Lags: Lags between 1 and 20 are tried, the lag minimizing the Akaike Information Criterion (AIC) is chosen.

(3) $\Delta$ : the first difference operator or the change in the variable.

(4) If test statistic > critical value, the null hypothesis of no causality is rejected.

(5) The null hypotheses are: (i) change in BC does not Granger-cause change in LOAN, (ii) change in LOAN does not Granger-cause change in BC, (iii) change in LOAN does not Granger-cause change in GDP and (iv) change in GDP does not Granger-cause change in LOAN.

(6) $* * *, * *$ and $*$ stands for the significance at 1,5 and $10 \%$ levels, respectively.

(7) Eviews software version 4.1 is used.

(8) For detailed description of the test see Granger (1969). 
in France, suggesting interdependence between the banking sector and the real sector.

The apparent contradiction in the results of the credit view hypothesis tests among these countries may be attributable to differences in financial structures; legal, regulatory and political factors; and the effectiveness of the accounting systems. Beck et al. (2001) find that economies grow faster in countries with higher levels of overall financialsector development and with legal systems that more effectively protect the rights of outside investors. Demirgüç-Kunt and Levine (2001) and Ergungor (2004) also argue that the development of legal systems affect the functioning of financial systems, and thus, economic growth. Demirgüç-Kunt and Huizinga (2001) present evidence for the impact of financial structure - the relative importance of banks vs. markets - on bank performance. They argue that countries differ widely in their relative reliance on bank vs. market finance.

\section{Vector Error Correction Model (VECM)}

The existence of cointegration between BC, LOAN and GDP leads us to use the VECM. The VECM is constructed by adding an adjustment parameter to the cointegration equation. Consequently, short-run adjustments correct deviations from the long-run equilibrium.

The following VECM is constructed with the dependent variables BC, LOAN and GDP. The fifth component of each equation is the error correction term (ECT) that is formed with the cointegrating vector. The sign and the size of the coefficient of the ECT in each equation reflect the direction and speed of adjustments in the dependent variable to deviations from the linear long-run relationship.

$$
\begin{aligned}
\Delta \mathrm{BC}_{t}= & d_{1}+a_{11}(L) \Delta \mathrm{BC}_{t-1}+a_{12}(L) \Delta \mathrm{LOAN}_{t-1} \\
& +a_{13}(L) \Delta \mathrm{GDP}_{t-1}+f_{1}\left(\mathrm{BC}_{t-1}\right. \\
& \left.+b_{12} \mathrm{LOAN}_{t-1}+b_{13} \mathrm{GDP}_{t-1}+c_{0}\right)+\varepsilon_{1 t} \\
\Delta \mathrm{LOAN}_{t}= & d_{2}+a_{21}(L) \Delta \mathrm{BC}_{t-1}+a_{22}(L) \Delta \mathrm{LOAN}_{t-1} \\
& +a_{23}(L) \Delta \mathrm{GDP}_{t-1}+f_{2}\left(\mathrm{BC}_{t-1}\right. \\
& \left.+b_{12} \mathrm{LOAN}_{t-1}+b_{13} \mathrm{GDP}_{t-1}+c_{0}\right)+\varepsilon_{2 t}
\end{aligned}
$$

$$
\begin{aligned}
\Delta \mathrm{GDP}_{t}= & d_{3}+a_{31}(L) \Delta \mathrm{BC}_{t-1}+a_{32}(L) \Delta \mathrm{LOAN}_{t-1} \\
& +a_{33}(L) \Delta \mathrm{GDP}_{t-1}+f_{3}\left(\mathrm{BC}_{t-1}\right. \\
& \left.+b_{12} \mathrm{LOAN}_{t-1}+b_{13} \mathrm{GDP}_{t-1}+c_{0}\right)+\varepsilon_{3 t}
\end{aligned}
$$

where $\Delta$ is the change operator; $d_{1}, d_{2}, d_{3}$ and $c_{0}$ are constants; $L$ is the lag operator $\left[a_{11}(L): a_{11.0} L^{0}+a_{11.1}\right.$ $L^{1}+\cdots$ (a polynomial in $\left.\left.L\right)\right] ; f_{1}, f_{2}$, and $f_{3}$ are the adjustment parameters; and $b_{12}$ and $b_{13}$ are the cointegration coefficients. Adjustment parameters and the coefficients of cointegration equations for each country are given in Table 5 .

\section{Variance Decomposition and Impulse- Response Function (IRF) Analyses}

Variance decomposition analysis and impulseresponse function analysis are used to find evidence that the banking sector affects the real sector, the real sector affects the banking sector, or both. We used the VECM in calculating the variance decomposition and impulse-response function among $\mathrm{BC}$, LOAN and GDP.

\section{Variance decomposition analyses}

Variance decomposition breaks down the variance of the forecast error for each variable into components that can be attributed to each of the endogenous variables.

If, as hypothesized, a higher $\mathrm{BC}$ leads to a higher LOAN and a higher LOAN leads to a higher GDP, then we would expect $\mathrm{BC}$ innovation to have a larger percentage than that of GDP innovation in the variance decomposition of LOAN. We would also expect LOAN innovation to have a larger percentage than that of $\mathrm{BC}$ in the variance decomposition of GDP. Table 6 shows the variance decompositions of $\mathrm{BC}, \mathrm{LOAN}$ and GDP for eleven countries.

To illustrate the interpretation of Table 6 , consider that $\mathrm{BC}$ innovations cause $100 \%$ of the variation in their forecast error in the first period, for Germany. LOAN and GDP innovations cause zero percent of the same variation. In the variance decomposition of LOAN, BC innovation yields much greater variation in LOAN forecast error relative to GDP $(17-35 \%$ vs. $0-12 \%)$. Thus, BC plays a more important role in explaining the variation in LOAN relative to GDP, as the credit view hypothesis would predict. Variance decomposition of LOAN yields similar results for other countries; BC innovation yields more variation in LOAN forecast error relative to GDP.

Again, taking Germany as an example, in the variance decomposition of GDP, LOAN innovation causes a much greater variation relative to $\mathrm{BC}$, as predicted by the credit view hypothesis $(2-43 \%$ vs. $0-11 \%)$. Variance decomposition results of the other countries (except for Austria, Italy, Mexico and 
Table 5. VECM regression results

\begin{tabular}{|c|c|c|c|c|}
\hline \multirow[b]{2}{*}{ Country } & \multicolumn{2}{|c|}{ Cointegration equation } & \multicolumn{2}{|c|}{ Adjustment parameter } \\
\hline & & Coefficient estimate & & Coefficient estimate \\
\hline Austria & $\begin{array}{l}\text { BC }(-1) \\
\text { LOAN }(-1) \\
\text { GDP }(-1) \\
\text { Constant }\end{array}$ & $\begin{array}{r}1.000 \\
47.222 \\
-69.223 \\
506.981\end{array}$ & $\begin{array}{l}\triangle \mathrm{BC} \\
\triangle \mathrm{LOAN} \\
\triangle \mathrm{GDP}\end{array}$ & $\begin{array}{r}0.002 \\
-0.003 \\
0.004\end{array}$ \\
\hline Finland & $\begin{array}{l}\text { BC }(-1) \\
\text { LOAN }(-1) \\
\text { GDP }(-1) \\
\text { Constant }\end{array}$ & $\begin{array}{r}1.000 \\
-2.615 \\
-1.131 \\
74.607\end{array}$ & $\begin{array}{l}\triangle \mathrm{BC} \\
\triangle \mathrm{LOAN} \\
\Delta \mathrm{GDP}\end{array}$ & $\begin{array}{r}-0.333 \\
0.027 \\
0.044\end{array}$ \\
\hline France & $\begin{array}{l}\text { BC }(-1) \\
\text { LOAN }(-1) \\
\text { GDP }(-1) \\
\text { Constant }\end{array}$ & $\begin{array}{r}1.000 \\
-1.167 \\
-0.500 \\
20.808\end{array}$ & $\begin{array}{l}\triangle \mathrm{BC} \\
\triangle \mathrm{LOAN} \\
\Delta \mathrm{GDP}\end{array}$ & $\begin{array}{r}-0.162 \\
0.038 \\
0.068\end{array}$ \\
\hline Germany & $\begin{array}{l}\text { BC }(-1) \\
\text { LOAN }(-1) \\
\text { GDP }(-1) \\
\text { Constant }\end{array}$ & $\begin{array}{r}1.000 \\
2.074 \\
-4.792 \\
44.946\end{array}$ & $\begin{array}{l}\triangle \mathrm{BC} \\
\triangle \mathrm{LOAN} \\
\triangle \mathrm{GDP}\end{array}$ & $\begin{array}{r}-0.055 \\
-0.002 \\
0.040\end{array}$ \\
\hline Italy & $\begin{array}{l}\text { BC }(-1) \\
\text { LOAN }(-1) \\
\text { GDP }(-1) \\
\text { Constant }\end{array}$ & $\begin{array}{r}1.000 \\
3.215 \\
-6.405 \\
71.954\end{array}$ & $\begin{array}{l}\triangle \mathrm{BC} \\
\triangle \mathrm{LOAN} \\
\triangle \mathrm{GDP}\end{array}$ & $\begin{array}{r}-0.467 \\
0.009 \\
-0.008\end{array}$ \\
\hline Korea & $\begin{array}{l}\text { BC }(-1) \\
\text { LOAN }(-1) \\
\text { GDP }(-1) \\
\text { Constant }\end{array}$ & $\begin{array}{r}1.000 \\
0.018 \\
-1.012 \\
1.110\end{array}$ & $\begin{array}{l}\triangle \mathrm{BC} \\
\triangle \mathrm{LOAN} \\
\triangle \mathrm{GDP}\end{array}$ & $\begin{array}{r}-0.563 \\
0.023 \\
0.040\end{array}$ \\
\hline Mexico & $\begin{array}{l}\text { BC }(-1) \\
\text { LOAN }(-1) \\
\text { GDP }(-1) \\
\text { Constant }\end{array}$ & $\begin{array}{r}1.000 \\
-1.757 \\
0.410 \\
11.303\end{array}$ & $\begin{array}{l}\triangle \mathrm{BC} \\
\triangle \mathrm{LOAN} \\
\triangle \mathrm{GDP}\end{array}$ & $\begin{array}{r}-0.284 \\
0.042 \\
0.012\end{array}$ \\
\hline Netherlands & $\begin{array}{l}\text { BC }(-1) \\
\text { LOAN }(-1) \\
\operatorname{GDP}(-1) \\
\text { Constant }\end{array}$ & $\begin{array}{r}1.000 \\
-0.161 \\
-1.741 \\
24.457\end{array}$ & $\begin{array}{l}\triangle \mathrm{BC} \\
\Delta \mathrm{LOAN} \\
\Delta \mathrm{GDP}\end{array}$ & $\begin{array}{r}-0.044 \\
0.214 \\
0.011\end{array}$ \\
\hline Portugal & $\begin{array}{l}\text { BC }(-1) \\
\text { LOAN }(-1) \\
\text { GDP }(-1) \\
\text { Constant }\end{array}$ & $\begin{array}{r}1.000 \\
0.944 \\
-4.019 \\
59.583\end{array}$ & $\begin{array}{l}\triangle \mathrm{BC} \\
\triangle \mathrm{LOAN} \\
\Delta \mathrm{GDP}\end{array}$ & $\begin{array}{r}-0.022 \\
0.024 \\
0.019\end{array}$ \\
\hline Spain & $\begin{array}{l}\text { BC }(-1) \\
\text { LOAN }(-1) \\
\text { GDP }(-1) \\
\text { Constant }\end{array}$ & $\begin{array}{r}1.000 \\
-0.021 \\
-1.241 \\
8.538\end{array}$ & $\begin{array}{l}\triangle \mathrm{BC} \\
\triangle \mathrm{LOAN} \\
\Delta \mathrm{GDP}\end{array}$ & $\begin{array}{r}0.015 \\
-0.152 \\
0.028\end{array}$ \\
\hline Turkey & $\begin{array}{l}\text { BC }(-1) \\
\text { LOAN }(-1) \\
\text { GDP }(-1) \\
\text { Constant }\end{array}$ & $\begin{array}{r}1.000 \\
0.077 \\
-1.184 \\
5.482\end{array}$ & $\begin{array}{l}\triangle \mathrm{BC} \\
\triangle \mathrm{LOAN} \\
\triangle \mathrm{GDP}\end{array}$ & $\begin{array}{l}-0.483 \\
-0.191 \\
-0.154\end{array}$ \\
\hline
\end{tabular}

Notes: (1) VECM is constructed by adding an adjustment parameter to the cointegration equation, consequently short-run adjustments correct deviations from the long-run equilibrium. Two important results of the VECM regression are the coefficients of cointegration equations and adjustment parameters.

(2) $\Delta$ : the first difference operator or the change in the variable. 
Table 6. Variance decomposition

\begin{tabular}{|c|c|c|c|c|c|c|c|c|c|c|c|c|c|}
\hline \multirow[b]{2}{*}{ Country } & \multirow[b]{2}{*}{ Period } & \multicolumn{4}{|c|}{$\begin{array}{l}\text { Column (a) } \\
\text { BC }\end{array}$} & \multicolumn{4}{|c|}{$\begin{array}{l}\text { Column (b) } \\
\text { LOAN }\end{array}$} & \multicolumn{4}{|c|}{$\begin{array}{l}\text { Column (c) } \\
\text { GDP }\end{array}$} \\
\hline & & SE & $\begin{array}{l}\varepsilon_{1 t} \\
(\mathrm{BC})\end{array}$ & $\begin{array}{l}\varepsilon_{2 t} \\
\text { (LOAN) }\end{array}$ & $\begin{array}{l}\varepsilon_{3 t} \\
(\mathrm{GDP})\end{array}$ & SE & $\begin{array}{l}\varepsilon_{1 t} \\
(\mathrm{BC})\end{array}$ & $\begin{array}{l}\varepsilon_{2 t} \\
(\text { LOAN) }\end{array}$ & $\begin{array}{l}\varepsilon_{3 t} \\
\text { (GDP) }\end{array}$ & SE & $\begin{array}{l}\varepsilon_{1 t} \\
(\mathrm{BC})\end{array}$ & $\begin{array}{l}\varepsilon_{2 t} \\
(\mathrm{LOAN})\end{array}$ & $\begin{array}{l}\varepsilon_{3 t} \\
\text { (GDP) }\end{array}$ \\
\hline \multirow[t]{10}{*}{ Austria } & 1 & 0.02 & 100.00 & 0.00 & 0.00 & 0.01 & 0.83 & 99.17 & 0.00 & 0.01 & 2.00 & 0.14 & 97.86 \\
\hline & 2 & 0.03 & 93.16 & 1.53 & 5.31 & 0.02 & 1.13 & 98.75 & 0.12 & 0.01 & 2.11 & 0.81 & 97.08 \\
\hline & 3 & 0.04 & 85.17 & 3.71 & 11.12 & 0.02 & 2.85 & 96.44 & 0.71 & 0.01 & 5.49 & 1.39 & 93.12 \\
\hline & 4 & 0.04 & 85.38 & 4.22 & 10.40 & 0.03 & 6.76 & 92.37 & 0.87 & 0.01 & 6.45 & 1.42 & 92.13 \\
\hline & 5 & 0.05 & 87.55 & 3.82 & 8.63 & 0.03 & 8.99 & 88.19 & 2.82 & 0.02 & 5.44 & 1.22 & 93.33 \\
\hline & 6 & 0.05 & 89.07 & 3.40 & 7.53 & 0.03 & 10.02 & 85.82 & 4.16 & 0.02 & 5.33 & 1.19 & 93.48 \\
\hline & 7 & 0.05 & 88.50 & 3.24 & 8.26 & 0.03 & 10.87 & 83.44 & 5.69 & 0.02 & 7.94 & 1.46 & 90.60 \\
\hline & 8 & 0.06 & 88.32 & 3.24 & 8.44 & 0.03 & 12.03 & 81.96 & 6.02 & 0.02 & 10.45 & 1.52 & 88.03 \\
\hline & 9 & 0.06 & 89.15 & 3.23 & 7.61 & 0.03 & 13.13 & 79.67 & 7.20 & 0.02 & 12.01 & 1.59 & 86.40 \\
\hline & 10 & 0.06 & 89.92 & 3.17 & 6.91 & 0.03 & 14.06 & 77.74 & 8.20 & 0.02 & 13.26 & 1.59 & 85.14 \\
\hline \multirow[t]{10}{*}{ Finland } & 1 & 0.10 & 100.00 & 0.00 & 0.00 & 0.02 & 3.07 & 96.93 & 0.00 & 0.01 & 0.45 & 6.19 & 93.36 \\
\hline & 2 & 0.13 & 99.28 & 0.00 & 0.72 & 0.03 & 2.16 & 97.33 & 0.50 & 0.02 & 4.71 & 8.22 & 87.07 \\
\hline & 3 & 0.14 & 97.44 & 0.31 & 2.25 & 0.04 & 1.72 & 97.93 & 0.35 & 0.03 & 3.15 & 9.33 & 87.52 \\
\hline & 4 & 0.15 & 93.03 & 3.74 & 3.23 & 0.05 & 3.41 & 96.35 & 0.24 & 0.03 & 2.56 & 7.70 & 89.74 \\
\hline & 5 & 0.16 & 88.99 & 7.37 & 3.64 & 0.07 & 3.60 & 96.23 & 0.18 & 0.03 & 2.04 & 5.80 & 92.16 \\
\hline & 6 & 0.17 & 82.25 & 14.41 & 3.34 & 0.08 & 3.76 & 96.11 & 0.13 & 0.04 & 2.07 & 5.56 & 92.38 \\
\hline & 7 & 0.18 & 74.48 & 22.56 & 2.96 & 0.09 & 3.86 & 96.01 & 0.13 & 0.04 & 1.91 & 6.04 & 92.05 \\
\hline & 8 & 0.19 & 66.46 & 30.70 & 2.84 & 0.09 & 3.88 & 95.98 & 0.14 & 0.04 & 1.84 & 8.96 & 89.21 \\
\hline & 9 & 0.20 & 59.64 & 37.42 & 2.94 & 0.10 & 3.79 & 96.00 & 0.21 & 0.05 & 1.62 & 12.45 & 85.93 \\
\hline & 10 & 0.21 & 53.79 & 42.77 & 3.44 & 0.11 & 3.71 & 95.99 & 0.30 & 0.05 & 1.42 & 17.63 & 80.95 \\
\hline \multirow[t]{10}{*}{ France } & 1 & 0.02 & 100.00 & 0.00 & 0.00 & 0.01 & 1.33 & 98.67 & 0.00 & 0.01 & 4.41 & 6.11 & 89.48 \\
\hline & 2 & 0.03 & 97.77 & 1.28 & 0.95 & 0.02 & 0.93 & 89.79 & 9.28 & 0.01 & 16.69 & 10.92 & 72.39 \\
\hline & 3 & 0.03 & 97.87 & 1.23 & 0.91 & 0.02 & 0.83 & 88.65 & 10.52 & 0.01 & 15.55 & 9.55 & 74.90 \\
\hline & 4 & 0.03 & 95.20 & 2.74 & 2.05 & 0.03 & 0.62 & 86.56 & 12.82 & 0.01 & 16.76 & 11.02 & 72.23 \\
\hline & 5 & 0.04 & 92.93 & 3.35 & 3.72 & 0.03 & 0.71 & 87.08 & 12.22 & 0.01 & 15.07 & 10.11 & 74.82 \\
\hline & 6 & 0.04 & 92.45 & 3.90 & 3.65 & 0.04 & 0.88 & 84.20 & 14.92 & 0.02 & 21.10 & 9.06 & 69.84 \\
\hline & 7 & 0.04 & 89.90 & 6.08 & 4.02 & 0.04 & 0.80 & 83.09 & 16.11 & 0.02 & 21.75 & 7.71 & 70.54 \\
\hline & 8 & 0.04 & 85.79 & 8.95 & 5.25 & 0.04 & 0.77 & 81.05 & 18.18 & 0.02 & 24.00 & 7.40 & 68.60 \\
\hline & 9 & 0.04 & 81.83 & 10.72 & 7.46 & 0.04 & 0.81 & 80.24 & 18.95 & 0.02 & 23.71 & 6.51 & 69.78 \\
\hline & 10 & 0.04 & 79.43 & 11.97 & 8.59 & 0.05 & 0.89 & 78.13 & 20.98 & 0.02 & 26.90 & 7.51 & 65.59 \\
\hline \multirow[t]{10}{*}{ Germany } & 1 & 0.04 & 100.00 & 0.00 & 0.00 & 0.01 & 24.92 & 75.08 & 0.00 & 0.01 & 0.09 & 2.13 & 97.78 \\
\hline & 2 & 0.05 & 97.90 & 1.55 & 0.55 & 0.02 & 35.26 & 64.00 & 0.74 & 0.02 & 0.26 & 1.90 & 97.84 \\
\hline & 3 & 0.06 & 93.18 & 1.84 & 4.98 & 0.02 & 33.09 & 64.74 & 2.17 & 0.02 & 1.20 & 2.71 & 96.10 \\
\hline & 4 & 0.06 & 90.87 & 1.63 & 7.49 & 0.03 & 31.85 & 64.43 & 3.72 & 0.03 & 5.38 & 21.29 & 73.33 \\
\hline & 5 & 0.06 & 86.50 & 2.09 & 11.41 & 0.03 & 28.31 & 66.73 & 4.95 & 0.03 & 9.72 & 27.36 & 62.92 \\
\hline & 6 & 0.07 & 78.85 & 5.58 & 15.58 & 0.04 & 25.58 & 67.79 & 6.62 & 0.04 & 10.91 & 32.57 & 56.52 \\
\hline & 7 & 0.07 & 72.37 & 7.70 & 19.93 & 0.04 & 22.89 & 68.93 & 8.18 & 0.04 & 11.12 & 35.57 & 53.31 \\
\hline & 8 & 0.08 & 65.29 & 11.45 & 23.26 & 0.04 & 20.81 & 69.43 & 9.76 & 0.05 & 10.68 & 38.92 & 50.40 \\
\hline & 9 & 0.08 & 59.24 & 14.82 & 25.95 & 0.05 & 18.91 & 70.05 & 11.04 & 0.05 & 10.16 & 41.20 & 48.65 \\
\hline & 10 & 0.09 & 53.66 & 18.61 & 27.72 & 0.05 & 17.43 & 70.34 & 12.22 & 0.05 & 9.53 & 43.27 & 47.20 \\
\hline \multirow[t]{10}{*}{ Italy } & 1 & 0.19 & 100.00 & 0.00 & 0.00 & 0.03 & 16.77 & 83.23 & 0.00 & 0.01 & 3.38 & 2.24 & 94.38 \\
\hline & 2 & 0.26 & 99.31 & 0.08 & 0.61 & 0.04 & 20.59 & 79.06 & 0.36 & 0.01 & 7.71 & 1.10 & 91.19 \\
\hline & 3 & 0.30 & 98.35 & 0.06 & 1.59 & 0.05 & 18.10 & 81.69 & 0.21 & 0.01 & 7.12 & 1.19 & 91.69 \\
\hline & 4 & 0.32 & 98.17 & 0.07 & 1.76 & 0.05 & 18.90 & 79.94 & 1.16 & 0.02 & 6.45 & 1.25 & 92.30 \\
\hline & 5 & 0.34 & 98.01 & 0.10 & 1.88 & 0.06 & 18.12 & 79.51 & 2.37 & 0.02 & 5.23 & 1.94 & 92.83 \\
\hline & 6 & 0.36 & 97.95 & 0.12 & 1.93 & 0.07 & 18.87 & 76.73 & 4.39 & 0.02 & 4.39 & 2.05 & 93.56 \\
\hline & 7 & 0.37 & 97.82 & 0.19 & 1.99 & 0.07 & 19.41 & 74.61 & 5.99 & 0.02 & 3.79 & 2.29 & 93.92 \\
\hline & 8 & 0.38 & 97.79 & 0.23 & 1.99 & 0.08 & 20.73 & 71.35 & 7.93 & 0.02 & 3.46 & 2.28 & 94.26 \\
\hline & 9 & 0.38 & 97.73 & 0.30 & 1.98 & 0.08 & 21.93 & 68.64 & 9.43 & 0.03 & 3.36 & 2.30 & 94.34 \\
\hline & 10 & 0.39 & 97.70 & 0.35 & 1.96 & 0.08 & 23.47 & 65.53 & 11.00 & 0.03 & 3.41 & 2.22 & 94.37 \\
\hline \multirow[t]{5}{*}{ Korea } & 1 & 0.08 & 100.00 & 0.00 & 0.00 & 0.02 & 0.73 & 99.27 & 0.00 & 0.02 & 17.09 & 19.54 & 63.37 \\
\hline & 2 & 0.08 & 96.58 & 2.77 & 0.64 & 0.02 & 0.43 & 98.69 & 0.88 & 0.03 & 16.85 & 16.17 & 66.98 \\
\hline & 3 & 0.09 & 79.03 & 20.29 & 0.68 & 0.03 & 2.66 & 95.51 & 1.82 & 0.03 & 18.70 & 16.87 & 64.42 \\
\hline & 4 & 0.10 & 75.89 & 22.74 & 1.37 & 0.03 & 2.83 & 95.61 & 1.56 & 0.03 & 21.66 & 18.29 & 60.05 \\
\hline & 5 & 0.11 & 80.65 & 18.22 & 1.13 & 0.03 & 9.51 & 89.31 & 1.18 & 0.04 & 36.79 & 13.48 & 49.73 \\
\hline
\end{tabular}


Table 6. Continued

\begin{tabular}{|c|c|c|c|c|c|c|c|c|c|c|c|c|c|}
\hline \multirow[b]{2}{*}{ Country } & \multirow[b]{2}{*}{ Period } & \multicolumn{4}{|c|}{$\begin{array}{l}\text { Column (a) } \\
\text { BC }\end{array}$} & \multicolumn{4}{|c|}{$\begin{array}{l}\text { Column (b) } \\
\text { LOAN }\end{array}$} & \multicolumn{4}{|c|}{$\begin{array}{l}\text { Column (c) } \\
\text { GDP }\end{array}$} \\
\hline & & SE & $\begin{array}{l}\varepsilon_{1 t} \\
(\mathrm{BC})\end{array}$ & $\begin{array}{l}\varepsilon_{2 t} \\
(\mathrm{LOAN})\end{array}$ & $\begin{array}{l}\varepsilon_{3 t} \\
(\mathrm{GDP})\end{array}$ & $\mathrm{SE}$ & $\begin{array}{l}\varepsilon_{1 t} \\
(\mathrm{BC})\end{array}$ & $\begin{array}{l}\varepsilon_{2 t} \\
(\mathrm{LOAN})\end{array}$ & $\begin{array}{l}\varepsilon_{3 t} \\
(\mathrm{GDP})\end{array}$ & $\mathrm{SE}$ & $\begin{array}{l}\varepsilon_{1 t} \\
(\mathrm{BC})\end{array}$ & $\begin{array}{l}\varepsilon_{2 t} \\
(\mathrm{LOAN})\end{array}$ & $\begin{array}{l}\varepsilon_{3 t} \\
(\mathrm{GDP})\end{array}$ \\
\hline & 6 & 0.11 & 79.62 & 19.27 & 1.11 & 0.04 & 11.59 & 87.45 & 0.96 & 0.04 & 45.88 & 12.17 & 41.94 \\
\hline & 7 & 0.11 & 79.17 & 19.44 & 1.40 & 0.04 & 12.94 & 86.04 & 1.02 & 0.04 & 51.60 & 10.94 & 37.45 \\
\hline & 8 & 0.11 & 78.29 & 20.34 & 1.37 & 0.04 & 12.78 & 86.23 & 0.99 & 0.05 & 54.16 & 13.22 & 32.62 \\
\hline & 9 & 0.12 & 79.74 & 18.98 & 1.28 & 0.04 & 13.12 & 85.97 & 0.91 & 0.05 & 58.29 & 12.09 & 29.62 \\
\hline & 10 & 0.12 & 77.63 & 20.47 & 1.90 & 0.05 & 12.85 & 86.28 & 0.86 & 0.05 & 58.57 & 12.43 & 29.00 \\
\hline \multirow[t]{10}{*}{ Mexico } & 1 & 0.43 & 100.00 & 0.00 & 0.00 & 0.06 & 2.04 & 97.96 & 0.00 & 0.03 & 10.65 & 7.97 & 81.38 \\
\hline & 2 & 0.51 & 97.30 & 1.70 & 1.00 & 0.08 & 8.56 & 88.77 & 2.67 & 0.05 & 11.64 & 3.79 & 84.57 \\
\hline & 3 & 0.54 & 92.18 & 6.60 & 1.22 & 0.10 & 16.40 & 80.33 & 3.26 & 0.07 & 11.07 & 2.20 & 86.73 \\
\hline & 4 & 0.58 & 90.48 & 7.74 & 1.78 & 0.11 & 27.19 & 66.60 & 6.21 & 0.08 & 11.64 & 1.50 & 86.85 \\
\hline & 5 & 0.59 & 87.97 & 9.02 & 3.01 & 0.13 & 26.89 & 65.64 & 7.47 & 0.10 & 11.75 & 1.18 & 87.07 \\
\hline & 6 & 0.60 & 86.25 & 9.86 & 3.89 & 0.13 & 26.13 & 65.16 & 8.71 & 0.11 & 12.15 & 1.05 & 86.80 \\
\hline & 7 & 0.60 & 84.64 & 10.08 & 5.28 & 0.14 & 25.26 & 64.83 & 9.91 & 0.12 & 12.98 & 1.01 & 86.01 \\
\hline & 8 & 0.61 & 83.39 & 10.04 & 6.57 & 0.15 & 24.31 & 64.69 & 11.00 & 0.12 & 13.86 & 1.01 & 85.12 \\
\hline & 9 & 0.61 & 82.75 & 9.97 & 7.28 & 0.15 & 23.49 & 64.83 & 11.68 & 0.13 & 14.70 & 1.04 & 84.27 \\
\hline & 10 & 0.62 & 82.23 & 9.91 & 7.86 & 0.15 & 22.94 & 64.86 & 12.19 & 0.14 & 15.47 & 1.07 & 83.46 \\
\hline \multirow[t]{10}{*}{ Netherlands } & 1 & 0.02 & 100.00 & 0.00 & 0.00 & 0.01 & 0.30 & 99.70 & 0.00 & 0.01 & 2.66 & 5.84 & 91.50 \\
\hline & 2 & 0.02 & 91.62 & 2.86 & 5.52 & 0.02 & 1.57 & 88.54 & 9.89 & 0.02 & 8.66 & 8.00 & 83.33 \\
\hline & 3 & 0.02 & 91.47 & 3.06 & 5.47 & 0.02 & 1.05 & 84.62 & 14.34 & 0.02 & 6.71 & 11.89 & 81.40 \\
\hline & 4 & 0.02 & 90.15 & 4.03 & 5.83 & 0.03 & 1.72 & 78.81 & 19.47 & 0.02 & 8.27 & 13.15 & 78.58 \\
\hline & 5 & 0.02 & 81.93 & 5.32 & 12.75 & 0.03 & 1.17 & 73.56 & 25.27 & 0.02 & 5.63 & 14.30 & 80.07 \\
\hline & 6 & 0.02 & 78.37 & 5.04 & 16.59 & 0.04 & 0.94 & 68.75 & 30.31 & 0.03 & 4.61 & 19.00 & 76.39 \\
\hline & 7 & 0.02 & 75.97 & 5.61 & 18.42 & 0.04 & 1.26 & 69.56 & 29.18 & 0.03 & 4.30 & 23.06 & 72.64 \\
\hline & 8 & 0.02 & 75.43 & 5.81 & 18.76 & 0.05 & 1.31 & 67.63 & 31.06 & 0.03 & 3.98 & 24.07 & 71.95 \\
\hline & 9 & 0.03 & 69.05 & 12.62 & 18.33 & 0.06 & 1.23 & 66.65 & 32.12 & 0.03 & 3.48 & 23.09 & 73.42 \\
\hline & 10 & 0.03 & 58.44 & 24.95 & 16.61 & 0.06 & 1.36 & 64.90 & 33.74 & 0.03 & 3.07 & 25.18 & 71.75 \\
\hline \multirow[t]{10}{*}{ Portugal } & 1 & 0.06 & 100.00 & 0.00 & 0.00 & 0.02 & 2.26 & 97.74 & 0.00 & 0.02 & 1.07 & 22.47 & 76.46 \\
\hline & 2 & 0.07 & 97.63 & 1.54 & 0.83 & 0.03 & 1.96 & 98.03 & 0.01 & 0.02 & 0.93 & 24.30 & 74.77 \\
\hline & 3 & 0.07 & 97.52 & 1.47 & 1.01 & 0.05 & 1.33 & 98.22 & 0.45 & 0.02 & 0.86 & 37.02 & 62.12 \\
\hline & 4 & 0.07 & 97.37 & 1.49 & 1.14 & 0.06 & 0.93 & 98.28 & 0.79 & 0.03 & 2.03 & 41.12 & 56.86 \\
\hline & 5 & 0.07 & 93.27 & 2.99 & 3.74 & 0.07 & 0.64 & 97.92 & 1.44 & 0.03 & 2.04 & 47.56 & 50.41 \\
\hline & 6 & 0.07 & 88.05 & 3.98 & 7.97 & 0.08 & 0.49 & 97.65 & 1.86 & 0.03 & 2.09 & 50.23 & 47.68 \\
\hline & 7 & 0.08 & 81.36 & 6.29 & 12.35 & 0.09 & 0.39 & 97.23 & 2.38 & 0.03 & 1.79 & 53.81 & 44.40 \\
\hline & 8 & 0.08 & 78.62 & 7.37 & 14.01 & 0.10 & 0.32 & 96.92 & 2.75 & 0.04 & 1.65 & 55.86 & 42.49 \\
\hline & 9 & 0.08 & 75.79 & 9.25 & 14.95 & 0.11 & 0.28 & 96.58 & 3.14 & 0.04 & 1.48 & 58.11 & 40.41 \\
\hline & 10 & 0.08 & 73.84 & 10.56 & 15.59 & 0.12 & 0.24 & 96.33 & 3.43 & 0.04 & 1.42 & 59.56 & 39.02 \\
\hline \multirow[t]{10}{*}{ Spain } & 1 & 0.02 & 100.00 & 0.00 & 0.00 & 0.01 & 1.31 & 98.69 & 0.00 & 0.01 & 2.41 & 10.56 & 87.03 \\
\hline & 2 & 0.02 & 99.92 & 0.01 & 0.07 & 0.02 & 3.17 & 89.21 & 7.62 & 0.01 & 6.06 & 15.91 & 78.03 \\
\hline & 3 & 0.03 & 98.67 & 0.27 & 1.07 & 0.02 & 4.11 & 90.16 & 5.73 & 0.02 & 5.49 & 22.67 & 71.84 \\
\hline & 4 & 0.03 & 97.45 & 0.36 & 2.19 & 0.03 & 7.30 & 86.15 & 6.54 & 0.02 & 7.94 & 25.58 & 66.48 \\
\hline & 5 & 0.03 & 95.54 & 1.99 & 2.48 & 0.03 & 8.78 & 84.71 & 6.51 & 0.02 & 6.44 & 25.54 & 68.02 \\
\hline & 6 & 0.03 & 89.84 & 6.11 & 4.06 & 0.04 & 12.28 & 78.99 & 8.73 & 0.02 & 5.68 & 27.31 & 67.00 \\
\hline & 7 & 0.03 & 84.22 & 11.59 & 4.19 & 0.04 & 14.45 & 76.31 & 9.24 & 0.02 & 6.07 & 30.06 & 63.87 \\
\hline & 8 & 0.03 & 78.00 & 17.99 & 4.01 & 0.05 & 16.87 & 72.88 & 10.25 & 0.02 & 5.52 & 33.07 & 61.41 \\
\hline & 9 & 0.03 & 70.83 & 24.38 & 4.79 & 0.06 & 18.08 & 70.99 & 10.94 & 0.02 & 5.13 & 34.18 & 60.68 \\
\hline & 10 & 0.03 & 63.18 & 30.37 & 6.45 & 0.06 & 19.53 & 68.32 & 12.16 & 0.02 & 5.05 & 35.46 & 59.49 \\
\hline \multirow[t]{10}{*}{ Turkey } & 1 & 0.14 & 100.00 & 0.00 & 0.00 & 0.06 & 5.21 & 94.79 & 0.00 & 0.06 & 5.14 & 0.15 & 94.71 \\
\hline & 2 & 0.16 & 95.37 & 0.16 & 4.46 & 0.09 & 3.20 & 94.90 & 1.91 & 0.08 & 3.16 & 3.39 & 93.46 \\
\hline & 3 & 0.17 & 92.60 & 3.30 & 4.10 & 0.11 & 2.42 & 91.83 & 5.75 & 0.10 & 2.04 & 2.84 & 95.12 \\
\hline & 4 & 0.17 & 92.08 & 3.47 & 4.45 & 0.14 & 3.25 & 83.10 & 13.66 & 0.12 & 2.03 & 2.54 & 95.43 \\
\hline & 5 & 0.18 & 87.48 & 7.98 & 4.54 & 0.17 & 2.56 & 78.18 & 19.26 & 0.14 & 5.71 & 2.68 & 91.62 \\
\hline & 6 & 0.18 & 82.77 & 10.06 & 7.16 & 0.20 & 2.59 & 71.72 & 25.69 & 0.16 & 7.21 & 3.62 & 89.17 \\
\hline & 7 & 0.19 & 79.50 & 10.53 & 9.97 & 0.22 & 2.72 & 64.18 & 33.10 & 0.18 & 9.11 & 4.82 & 86.07 \\
\hline & 8 & 0.20 & 70.37 & 9.52 & 20.11 & 0.25 & 4.34 & 53.91 & 41.75 & 0.20 & 9.95 & 5.65 & 84.40 \\
\hline & 9 & 0.21 & 61.80 & 10.62 & 27.57 & 0.29 & 5.67 & 46.41 & 47.92 & 0.23 & 10.66 & 6.05 & 83.30 \\
\hline & 10 & 0.23 & 55.45 & 11.65 & 32.89 & 0.32 & 7.11 & 39.87 & 53.01 & 0.25 & 11.57 & 6.68 & 81.76 \\
\hline
\end{tabular}

Notes: (1) Variance decompositions of BC, LOAN and GDP are presented for eleven countries. Variance decomposition breaks down the variance of the forecast error for each variable into components that can be attributed to each of the endogenous variables.

(2) BC: Bank capital.

(3) LOAN: Loans to private sector.

(4) GDP: Gross domestic product.

(5) SE: Forecast error. 
Turkey) are similar for the initial periods, suggesting that the banking sector affects the real sector. In brief, the variance-decomposition analysis results support the credit view hypothesis for the countries in our sample, except for Austria, Italy, Mexico and Turkey.

The reverse relationship, that is, the real sector affecting the banking sector, holds with a lag for France, the Netherlands and Turkey.

\section{Impulse-response function analysis}

An impulse-response function traces the effect of a one-time shock to an endogenous variable on current and future values of itself and of the other endogenous variables. Impulse-response function analysis may indicate several points relevant to the credit view hypothesis. One standard deviation(SD) of a variable's innovation may affect the other variable negatively, positively, or both, during the period. Impulse-response function analysis shows the response of an endogenous variable $i$ at time $t+s$ to the changes in errors of the other variable $j$ at time $t$. More specifically,

$$
\psi_{s}=\frac{\partial y_{i, t+s}}{\partial \varepsilon_{j t}}
$$

where $y$ is the vector of endogenous variables, and $\varepsilon$ is the vector of the error term. If the credit view hypothesis holds, then we expect the $\mathrm{BC}$ innovation to affect LOAN positively, because a higher $\mathrm{BC}$ increases the available cushion that banks use to protect themselves against defaults and also relieves regulatory constraints. Similarly, we expect LOAN innovation to affect GDP positively, because a higher volume of loans increases economic activity.

Estimates of the impulse-response function analysis are shown in Table 7. Again, taking Germany as an example, one SD BC innovation affects LOAN positively. Similarly, LOAN innovation affects GDP positively and more strongly than BC for all periods. Impulse-response function estimates also yield consistent results for the other countries. One SD LOAN innovation affects GDP positively for either all periods or up to some periods in the future for Austria, Finland, Germany, Korea, the Netherlands, Portugal, Spain and Turkey, suggesting that the banking sector affects the real sector in these countries $^{5}$. This relationship is unstable in France, Italy and Mexico.

\section{Conclusion}

In this article, we empirically investigated both the validity of the credit view hypothesis, which asserts that the banking sector affects economic performance, and the causal link between the banking sector and the real sector. Results of cointegration tests, Granger causality tests and variance decomposition and impulse-response function analyses suggest that significant links exist between the banking sector and the real sector in many countries in the sample.

After performing unit root tests, we observed that level data were nonstationary and that the first differenced data were stationary. Then, Johansen cointegration tests showed that BC, LOAN, and GDP co-move in time, suggesting the use of the VECM. Granger causality tests indicated that the banking sector Granger-causes the real sector in France, Germany, Korea and the Netherlands. Thus, the credit view holds in those countries that have more stable financial systems and larger banking sectors, especially when compared to those of Mexico and Turkey. However, in looking at Austria, Finland, Italy, Portugal and Spain, we did not observe Granger causality from the banking sector to the real sector, although the sizes of these banking sectors, measured by the asset-to-GDP ratios in this study, are not small. This result may be due to macroeconomic structural factors that would decrease the efficiency of the banking sector. In particular, a country's budget deficit should be analyzed. In a country with a large deficit, the credit may not be allocated efficiently, and therefore, even a large banking sector will not have the desired effect on economic growth.

When we include short-run dynamics in the analysis, variance decomposition of VECM supports the credit view hypothesis that the banking sector affects the real sector for the countries in our sample, except for Austria, Italy, Mexico and Turkey. Impulse-response function analysis also supports the credit view hypothesis in most of the countries. One SD LOAN innovation affects GDP positively for nearly all periods in Austria, Finland, Germany, Korea, the Netherlands, Portugal, Spain and Turkey, suggesting that the banking sector affects the real sector in these countries. This relationship is unstable in France, Italy and Mexico. In brief, the hypothesis that the banking sector affects the real sector is supported by both variance decomposition and impulse-response function analyses for Finland, Germany, Korea, the Netherlands, Portugal and

${ }^{5}$ Although, sample periods partially overlap, our results are consistent with the findings of Anari et al. (2002) for Finland. 
Table 7. Impulse-response function

\begin{tabular}{|c|c|c|c|c|c|c|c|c|c|c|}
\hline \multirow[b]{2}{*}{ Country } & \multirow[b]{2}{*}{ Period } & \multicolumn{3}{|c|}{$\begin{array}{l}\text { Column (a) } \\
\text { BC, } y_{1, t+s}\end{array}$} & \multicolumn{3}{|c|}{$\begin{array}{l}\text { Column (b) } \\
\text { LOAN, } y_{2, t+s}\end{array}$} & \multicolumn{3}{|c|}{$\begin{array}{l}\text { Column (c) } \\
\text { GDP, } y_{3, t+s}\end{array}$} \\
\hline & & $\begin{array}{l}\varepsilon_{1 t} \\
(\mathrm{BC})\end{array}$ & $\begin{array}{l}\varepsilon_{2 t} \\
(\mathrm{LOAN})\end{array}$ & $\begin{array}{l}\varepsilon_{3 t} \\
(\mathrm{GDP})\end{array}$ & $\begin{array}{l}\varepsilon_{1 t} \\
(\mathrm{BC})\end{array}$ & $\begin{array}{l}\varepsilon_{2 t} \\
(\mathrm{LOAN})\end{array}$ & $\begin{array}{l}\varepsilon_{3 t} \\
\text { (GDP) }\end{array}$ & $\begin{array}{l}\varepsilon_{1 t} \\
(\mathrm{BC})\end{array}$ & $\begin{array}{l}\varepsilon_{2 t} \\
(\mathrm{LOAN})\end{array}$ & $\begin{array}{l}\varepsilon_{3 t} \\
(\mathrm{GDP})\end{array}$ \\
\hline \multirow[t]{10}{*}{ Austria } & 1 & 0.021 & 0.000 & 0.000 & 0.001 & 0.015 & 0.000 & -0.002 & 0.000 & 0.012 \\
\hline & 2 & 0.022 & 0.004 & 0.007 & 0.002 & 0.012 & 0.001 & -0.001 & 0.001 & 0.004 \\
\hline & 3 & 0.017 & 0.006 & 0.010 & 0.003 & 0.013 & 0.002 & 0.003 & 0.001 & 0.003 \\
\hline & 4 & 0.016 & 0.004 & 0.005 & 0.005 & 0.009 & 0.001 & 0.001 & 0.000 & 0.000 \\
\hline & 5 & 0.019 & 0.003 & -0.001 & 0.005 & 0.008 & 0.004 & 0.001 & 0.000 & 0.007 \\
\hline & 6 & 0.019 & 0.002 & 0.002 & 0.004 & 0.006 & 0.004 & 0.001 & 0.000 & 0.004 \\
\hline & 7 & 0.017 & 0.003 & 0.007 & 0.004 & 0.005 & 0.004 & 0.003 & 0.001 & 0.004 \\
\hline & 8 & 0.017 & 0.003 & 0.006 & 0.004 & 0.004 & 0.002 & 0.003 & 0.001 & 0.001 \\
\hline & 9 & 0.019 & 0.003 & 0.002 & 0.004 & 0.003 & 0.004 & 0.003 & 0.001 & 0.004 \\
\hline & 10 & 0.019 & 0.003 & 0.001 & 0.004 & 0.003 & 0.004 & 0.002 & 0.000 & 0.003 \\
\hline \multirow[t]{10}{*}{ Finland } & 1 & 0.104 & 0.000 & 0.000 & 0.003 & 0.018 & 0.000 & -0.001 & 0.004 & 0.014 \\
\hline & 2 & 0.069 & 0.001 & 0.011 & 0.003 & 0.022 & -0.002 & -0.004 & 0.004 & 0.011 \\
\hline & 3 & 0.049 & 0.008 & -0.017 & 0.003 & 0.029 & -0.001 & -0.002 & 0.006 & 0.016 \\
\hline & 4 & 0.050 & 0.028 & -0.017 & 0.008 & 0.033 & -0.001 & 0.001 & 0.002 & 0.014 \\
\hline & 5 & 0.038 & 0.032 & -0.014 & 0.007 & 0.036 & 0.001 & 0.001 & 0.001 & 0.017 \\
\hline & 6 & 0.025 & 0.046 & -0.004 & 0.008 & 0.038 & 0.000 & 0.002 & -0.003 & 0.014 \\
\hline & 7 & 0.023 & 0.055 & -0.001 & 0.008 & 0.039 & 0.001 & 0.002 & -0.005 & 0.015 \\
\hline & 8 & 0.018 & 0.062 & 0.009 & 0.008 & 0.038 & 0.002 & 0.002 & -0.008 & 0.013 \\
\hline & 9 & 0.017 & 0.064 & 0.013 & 0.007 & 0.037 & 0.003 & 0.001 & -0.010 & 0.014 \\
\hline & 10 & 0.016 & 0.065 & 0.019 & 0.006 & 0.035 & 0.004 & 0.001 & -0.013 & 0.013 \\
\hline \multirow[t]{10}{*}{ France } & 1 & 0.024 & 0.000 & 0.000 & -0.002 & 0.013 & 0.000 & 0.002 & 0.002 & 0.008 \\
\hline & 2 & 0.020 & -0.004 & -0.003 & -0.001 & 0.012 & 0.006 & 0.004 & -0.003 & 0.003 \\
\hline & 3 & 0.007 & 0.000 & 0.000 & 0.001 & 0.013 & 0.005 & 0.002 & 0.001 & 0.005 \\
\hline & 4 & 0.004 & 0.004 & 0.004 & 0.000 & 0.012 & 0.006 & 0.002 & 0.002 & 0.003 \\
\hline & 5 & 0.009 & 0.003 & 0.005 & -0.002 & 0.014 & 0.005 & 0.003 & 0.002 & 0.007 \\
\hline & 6 & 0.011 & 0.003 & 0.002 & -0.002 & 0.014 & 0.008 & 0.004 & -0.001 & 0.003 \\
\hline & 7 & 0.007 & 0.006 & 0.003 & -0.001 & 0.013 & 0.007 & 0.003 & 0.000 & 0.006 \\
\hline & 8 & 0.005 & 0.007 & 0.005 & -0.001 & 0.012 & 0.008 & 0.003 & -0.001 & 0.003 \\
\hline & 9 & 0.005 & 0.006 & 0.007 & -0.001 & 0.012 & 0.007 & 0.003 & 0.000 & 0.006 \\
\hline & 10 & 0.006 & 0.006 & 0.005 & -0.002 & 0.011 & 0.009 & 0.005 & -0.002 & 0.003 \\
\hline \multirow[t]{10}{*}{ Germany } & 1 & 0.039 & 0.000 & 0.000 & 0.007 & 0.012 & 0.000 & 0.000 & 0.002 & 0.012 \\
\hline & 2 & 0.030 & -0.006 & 0.004 & 0.009 & 0.010 & 0.002 & 0.001 & 0.002 & 0.013 \\
\hline & 3 & 0.024 & -0.005 & 0.012 & 0.008 & 0.012 & 0.003 & 0.002 & 0.003 & 0.012 \\
\hline & 4 & 0.018 & 0.001 & 0.011 & 0.007 & 0.011 & 0.004 & 0.006 & 0.012 & 0.012 \\
\hline & 5 & 0.014 & 0.005 & 0.014 & 0.006 & 0.013 & 0.005 & 0.008 & 0.012 & 0.012 \\
\hline & 6 & 0.013 & 0.013 & 0.016 & 0.006 & 0.013 & 0.006 & 0.007 & 0.014 & 0.012 \\
\hline & 7 & 0.010 & 0.012 & 0.018 & 0.005 & 0.014 & 0.006 & 0.007 & 0.013 & 0.012 \\
\hline & 8 & 0.008 & 0.017 & 0.018 & 0.005 & 0.014 & 0.007 & 0.006 & 0.014 & 0.012 \\
\hline & 9 & 0.008 & 0.018 & 0.019 & 0.005 & 0.015 & 0.008 & 0.005 & 0.014 & 0.012 \\
\hline & 10 & 0.008 & 0.020 & 0.018 & 0.005 & 0.015 & 0.008 & 0.004 & 0.014 & 0.011 \\
\hline \multirow[t]{10}{*}{ Italy } & 1 & 0.190 & 0.000 & 0.000 & -0.011 & 0.024 & 0.000 & 0.001 & -0.001 & 0.007 \\
\hline & 2 & 0.171 & -0.007 & -0.020 & -0.012 & 0.022 & -0.002 & 0.003 & 0.000 & 0.008 \\
\hline & 3 & 0.146 & -0.001 & -0.032 & -0.011 & 0.028 & 0.000 & 0.002 & -0.001 & 0.009 \\
\hline & 4 & 0.126 & -0.004 & -0.021 & -0.012 & 0.023 & 0.005 & 0.002 & -0.001 & 0.008 \\
\hline & 5 & 0.114 & 0.007 & -0.019 & -0.011 & 0.025 & 0.007 & 0.001 & -0.002 & 0.009 \\
\hline & 6 & 0.100 & 0.006 & -0.016 & -0.013 & 0.021 & 0.010 & 0.000 & -0.001 & 0.009 \\
\hline & 7 & 0.089 & 0.010 & -0.015 & -0.013 & 0.021 & 0.011 & 0.000 & -0.002 & 0.009 \\
\hline & 8 & 0.078 & 0.008 & -0.011 & -0.014 & 0.017 & 0.012 & -0.001 & -0.001 & 0.008 \\
\hline & 9 & 0.070 & 0.011 & -0.009 & -0.015 & 0.017 & 0.012 & -0.001 & -0.001 & 0.008 \\
\hline & 10 & 0.061 & 0.009 & -0.007 & -0.016 & 0.015 & 0.013 & -0.002 & -0.001 & 0.008 \\
\hline \multirow[t]{3}{*}{ Korea } & 1 & 0.079 & 0.000 & 0.000 & 0.002 & 0.018 & 0.000 & 0.008 & 0.009 & 0.016 \\
\hline & 2 & 0.027 & 0.014 & 0.007 & 0.000 & 0.015 & 0.002 & 0.007 & 0.006 & 0.014 \\
\hline & 3 & 0.000 & 0.040 & 0.004 & 0.004 & 0.011 & 0.003 & 0.007 & 0.006 & 0.011 \\
\hline
\end{tabular}


Table 7. Continued

\begin{tabular}{|c|c|c|c|c|c|c|c|c|c|c|}
\hline \multirow[b]{2}{*}{ Country } & \multirow[b]{2}{*}{ Period } & \multicolumn{3}{|c|}{$\begin{array}{l}\text { Column (a) } \\
\text { BC, } y_{1, t+s}\end{array}$} & \multicolumn{3}{|c|}{$\begin{array}{l}\text { Column (b) } \\
\text { LOAN, } y_{2, t+s}\end{array}$} & \multicolumn{3}{|c|}{$\begin{array}{l}\text { Column (c) } \\
\text { GDP, } y_{3, t+s}\end{array}$} \\
\hline & & $\begin{array}{l}\varepsilon_{1 t} \\
(\mathrm{BC})\end{array}$ & $\begin{array}{l}\varepsilon_{2 t} \\
(\mathrm{LOAN})\end{array}$ & $\begin{array}{l}\varepsilon_{3 t} \\
(\mathrm{GDP})\end{array}$ & $\begin{array}{l}\varepsilon_{1 t} \\
(\mathrm{BC})\end{array}$ & $\begin{array}{l}\varepsilon_{2 t} \\
\text { (LOAN) }\end{array}$ & $\begin{array}{l}\varepsilon_{3 t} \\
(\mathrm{GDP})\end{array}$ & $\begin{array}{l}\varepsilon_{1 t} \\
(\mathrm{BC})\end{array}$ & $\begin{array}{l}\varepsilon_{2 t} \\
(\mathrm{LOAN})\end{array}$ & $\begin{array}{l}\varepsilon_{3 t} \\
(\mathrm{GDP})\end{array}$ \\
\hline & 4 & -0.006 & 0.018 & 0.008 & 0.002 & 0.011 & 0.000 & 0.007 & 0.005 & 0.004 \\
\hline & 5 & 0.048 & -0.003 & 0.002 & 0.009 & 0.014 & 0.000 & 0.018 & 0.003 & 0.011 \\
\hline & 6 & 0.016 & -0.014 & 0.002 & 0.008 & 0.016 & -0.001 & 0.017 & -0.005 & 0.007 \\
\hline & 7 & 0.006 & 0.006 & -0.006 & 0.007 & 0.013 & -0.002 & 0.015 & -0.002 & 0.003 \\
\hline & 8 & -0.010 & 0.013 & -0.001 & 0.004 & 0.011 & -0.001 & 0.015 & -0.009 & 0.002 \\
\hline & 9 & 0.036 & -0.010 & 0.003 & 0.005 & 0.012 & 0.000 & 0.017 & -0.004 & 0.005 \\
\hline & 10 & 0.005 & -0.017 & 0.010 & 0.003 & 0.010 & 0.000 & 0.007 & -0.004 & 0.002 \\
\hline \multirow[t]{10}{*}{ Mexico } & 1 & 0.431 & 0.000 & 0.000 & 0.008 & 0.059 & 0.000 & -0.011 & -0.010 & 0.030 \\
\hline & 2 & 0.262 & 0.067 & -0.051 & 0.021 & 0.043 & -0.013 & -0.014 & -0.004 & 0.037 \\
\hline & 3 & 0.099 & 0.120 & 0.030 & 0.032 & 0.046 & -0.012 & -0.015 & -0.002 & 0.044 \\
\hline & 4 & 0.196 & 0.084 & -0.050 & 0.045 & 0.035 & -0.023 & -0.017 & 0.001 & 0.045 \\
\hline & 5 & 0.082 & 0.076 & -0.068 & 0.027 & 0.041 & -0.019 & -0.017 & 0.002 & 0.045 \\
\hline & 6 & -0.005 & 0.061 & -0.058 & 0.021 & 0.036 & -0.020 & -0.017 & 0.003 & 0.043 \\
\hline & 7 & 0.005 & 0.039 & -0.073 & 0.017 & 0.033 & -0.020 & -0.019 & 0.004 & 0.040 \\
\hline & 8 & -0.026 & 0.022 & -0.072 & 0.011 & 0.028 & -0.019 & -0.019 & 0.004 & 0.038 \\
\hline & 9 & -0.036 & 0.013 & -0.055 & 0.008 & 0.026 & -0.016 & -0.019 & 0.005 & 0.036 \\
\hline & 10 & -0.009 & 0.004 & -0.049 & 0.007 & 0.022 & -0.014 & -0.019 & 0.005 & 0.034 \\
\hline \multirow[t]{10}{*}{ Netherlands } & 1 & 0.017 & 0.000 & 0.000 & 0.001 & 0.012 & 0.000 & -0.002 & 0.003 & 0.012 \\
\hline & 2 & 0.012 & 0.004 & 0.005 & -0.002 & 0.009 & 0.005 & 0.004 & 0.003 & 0.007 \\
\hline & 3 & 0.003 & 0.001 & 0.000 & -0.001 & 0.012 & 0.006 & 0.000 & 0.004 & 0.007 \\
\hline & 4 & -0.001 & 0.002 & 0.002 & -0.003 & 0.012 & 0.008 & 0.003 & 0.003 & 0.006 \\
\hline & 5 & -0.001 & 0.003 & 0.006 & -0.001 & 0.015 & 0.011 & 0.000 & 0.005 & 0.012 \\
\hline & 6 & 0.002 & 0.000 & 0.005 & -0.001 & 0.015 & 0.013 & 0.000 & 0.007 & 0.008 \\
\hline & 7 & -0.004 & -0.002 & 0.004 & -0.003 & 0.020 & 0.012 & -0.001 & 0.007 & 0.007 \\
\hline & 8 & -0.002 & -0.001 & 0.002 & -0.003 & 0.018 & 0.014 & 0.001 & 0.005 & 0.007 \\
\hline & 9 & -0.001 & 0.007 & 0.003 & -0.003 & 0.022 & 0.017 & 0.001 & 0.005 & 0.011 \\
\hline & 10 & -0.004 & 0.011 & 0.004 & -0.004 & 0.021 & 0.017 & 0.000 & 0.007 & 0.009 \\
\hline \multirow[t]{10}{*}{ Portugal } & 1 & 0.055 & 0.000 & 0.000 & 0.003 & 0.022 & 0.000 & -0.002 & 0.008 & 0.014 \\
\hline & 2 & 0.036 & -0.008 & 0.006 & 0.003 & 0.024 & 0.000 & 0.001 & 0.005 & 0.008 \\
\hline & 3 & 0.020 & -0.002 & 0.003 & 0.003 & 0.035 & 0.003 & 0.001 & 0.011 & 0.009 \\
\hline & 4 & -0.006 & -0.001 & 0.003 & 0.001 & 0.035 & 0.004 & 0.003 & 0.008 & 0.005 \\
\hline & 5 & -0.008 & 0.009 & 0.012 & 0.000 & 0.040 & 0.007 & 0.002 & 0.011 & 0.007 \\
\hline & 6 & -0.004 & 0.008 & 0.016 & 0.000 & 0.039 & 0.007 & 0.002 & 0.009 & 0.006 \\
\hline & 7 & 0.005 & 0.013 & 0.017 & 0.000 & 0.042 & 0.009 & 0.001 & 0.011 & 0.007 \\
\hline & 8 & 0.007 & 0.009 & 0.012 & 0.000 & 0.040 & 0.009 & 0.001 & 0.010 & 0.006 \\
\hline & 9 & 0.006 & 0.012 & 0.010 & 0.000 & 0.041 & 0.010 & 0.001 & 0.011 & 0.007 \\
\hline & 10 & 0.003 & 0.010 & 0.008 & 0.000 & 0.040 & 0.010 & 0.001 & 0.010 & 0.006 \\
\hline \multirow[t]{10}{*}{ Spain } & 1 & 0.019 & 0.000 & 0.000 & 0.002 & 0.013 & 0.000 & -0.002 & 0.004 & 0.011 \\
\hline & 2 & 0.015 & 0.000 & 0.001 & -0.003 & 0.009 & 0.005 & 0.003 & 0.004 & 0.005 \\
\hline & 3 & 0.006 & -0.001 & -0.003 & -0.004 & 0.015 & 0.003 & -0.001 & 0.005 & 0.003 \\
\hline & 4 & 0.003 & 0.001 & -0.003 & -0.006 & 0.013 & 0.004 & 0.003 & 0.004 & 0.002 \\
\hline & 5 & 0.003 & 0.003 & 0.002 & -0.006 & 0.017 & 0.005 & -0.001 & 0.004 & 0.007 \\
\hline & 6 & 0.002 & 0.006 & 0.004 & -0.009 & 0.016 & 0.008 & -0.001 & 0.004 & 0.006 \\
\hline & 7 & 0.000 & 0.007 & 0.002 & -0.010 & 0.019 & 0.007 & -0.002 & 0.005 & 0.005 \\
\hline & 8 & -0.001 & 0.008 & 0.001 & -0.012 & 0.018 & 0.009 & 0.000 & 0.005 & 0.004 \\
\hline & 9 & -0.002 & 0.009 & 0.003 & -0.012 & 0.020 & 0.009 & -0.001 & 0.005 & 0.006 \\
\hline & 10 & -0.004 & 0.010 & 0.005 & -0.013 & 0.019 & 0.011 & -0.002 & 0.006 & 0.006 \\
\hline \multirow[t]{6}{*}{ Turkey } & 1 & 0.145 & 0.000 & 0.000 & 0.014 & 0.059 & 0.000 & 0.014 & 0.002 & 0.059 \\
\hline & 2 & 0.066 & -0.007 & -0.034 & 0.009 & 0.067 & 0.013 & 0.005 & 0.015 & 0.053 \\
\hline & 3 & 0.043 & -0.030 & 0.004 & 0.007 & 0.062 & 0.024 & -0.003 & 0.009 & 0.064 \\
\hline & 4 & -0.009 & -0.008 & 0.011 & -0.017 & 0.058 & 0.042 & -0.009 & 0.008 & 0.061 \\
\hline & 5 & -0.002 & 0.038 & -0.010 & -0.010 & 0.079 & 0.053 & -0.028 & 0.012 & 0.058 \\
\hline & 6 & 0.021 & 0.030 & 0.031 & -0.017 & 0.078 & 0.068 & -0.027 & 0.020 & 0.070 \\
\hline
\end{tabular}


Table 7. Continued

\begin{tabular}{|c|c|c|c|c|c|c|c|c|c|c|}
\hline \multirow[t]{2}{*}{ Country } & \multirow[t]{2}{*}{ Period } & \multicolumn{3}{|c|}{$\begin{array}{l}\text { Column (a) } \\
\text { BC, } y_{1, t+s}\end{array}$} & \multicolumn{3}{|c|}{$\begin{array}{l}\text { Column (b) } \\
\text { LOAN, } y_{2, t+s}\end{array}$} & \multicolumn{3}{|c|}{$\begin{array}{l}\text { Column (c) } \\
\text { GDP, } y_{3, t+s}\end{array}$} \\
\hline & & $\begin{array}{l}\varepsilon_{1 t} \\
(\mathrm{BC})\end{array}$ & $\begin{array}{l}\varepsilon_{2 t} \\
(\mathrm{LOAN})\end{array}$ & $\begin{array}{l}\varepsilon_{3 t} \\
(\mathrm{GDP})\end{array}$ & $\begin{array}{l}\varepsilon_{1 t} \\
(\mathrm{BC})\end{array}$ & $\begin{array}{l}\varepsilon_{2 t} \\
(\mathrm{LOAN})\end{array}$ & $\begin{array}{l}\varepsilon_{3 t} \\
(\mathrm{GDP})\end{array}$ & $\begin{array}{l}\varepsilon_{1 t} \\
(\mathrm{BC})\end{array}$ & $\begin{array}{l}\varepsilon_{2 t} \\
(\mathrm{LOAN})\end{array}$ & $\begin{array}{l}\varepsilon_{3 t} \\
\text { (GDP) }\end{array}$ \\
\hline & 7 & 0.014 & 0.018 & 0.033 & -0.019 & 0.067 & 0.081 & -0.034 & 0.026 & 0.076 \\
\hline & 8 & -0.006 & 0.009 & 0.067 & -0.038 & 0.052 & 0.102 & -0.034 & 0.028 & 0.085 \\
\hline & 9 & -0.004 & 0.032 & 0.067 & -0.043 & 0.056 & 0.110 & -0.039 & 0.029 & 0.094 \\
\hline & 10 & -0.019 & 0.034 & 0.066 & -0.051 & 0.052 & 0.122 & -0.043 & 0.034 & 0.096 \\
\hline
\end{tabular}

Notes: (1) Estimates of the impulse-response function analysis are shown. Impulse-response function traces the effect of a one-time shock to one of the endogenous variables on current and future values of itself and the other endogenous variables. One SD of one variable's innovation may affect the other variable negatively, positively, or both, throughout the period. Impulse-response function analysis shows the response of an endogenous variable to the changes in errors of the other variables.

(2) BC: Bank capital.

(3) LOAN: Loans to private sector.

(4) GDP: Gross domestic product.

(5) $\varepsilon$ : Innovation.

Spain. Although Austria, France and Turkey provide support for the hypothesis that the banking sector affects the real sector in one of the tests, Italy and Mexico fail to do so in all of these tests.

To summarize, the banking sector Granger-causes the real sector, and the credit view holds in France, Germany, Korea and the Netherlands. According to variance decomposition and impulse-response function analyses, the banking sector affects the real sector, supporting the credit view in all countries in the sample except for Italy and Mexico. This is an expected result, especially for Mexico, which has a relatively small banking sector. Although the banking sector is not small in Italy, the high deficit as a percentage of GDP in the period 1990 to $1996^{6}$ may be an explanation for the lack of evidence of interdependence between the banking sector and the real sector. Furthermore, other factors such as differences in the political, legal, and financial systems and in the macroeconomic conditions of the countries might lead to different results in the credit view hypothesis tests.

\section{References}

Anari, A., Kolari, J., Pynnönen, S. and Suvanto, A. (2002) Further evidence on the credit view: the case of Finland, Applied Economics, 34, 267-78.

Bates, S. (2005) Global measure of causal intensity between real and financial spheres, Applied Economics, 37, 1635-42.
Beck, T., Demirgüç-Kunt, A., Levine, R. and Maksimovic, V. (2001) Financial structure and economic development: firm, industry and country evidence, in Financial Structure and Economic Growth: A Cross-Country Comparison of Banks, Markets, and Development (Eds) A. Demirgüç-Kunt and R. Levine, MIT Press, Cambridge, MA, pp. 189-241.

Bernanke, B. S. and Gertler, M. (1987) Banking and macroeconomic equilibrium, in New Approaches to Monetary Economics (Eds) W. Barnett and K. Singleton, Cambridge University Press, New York, pp. 89-110.

Chang, T. and Caudill, S. B. (2005) Financial development and economic growth: the case of Taiwan, Applied Economics, 37, 1329-35.

Chen, N. (2001) Bank net worth, asset prices and economic activity, Journal of Monetary Economics, 48, 415-36.

Demirgüç-Kunt, A. and Huizinga, H. (2001) Financial structure and bank profitability, in Financial Structure and Economic Growth: A Cross-Country Comparison of Banks, Markets, and Development (Eds) A. DemirgüçKunt and R. Levine, MIT Press, Cambridge, MA, pp. 243-61.

Demirgüç-Kunt, A. and Levine, R. (2001) Bank-based and market-based financial systems: cross-country comparisons, in Financial Structure and Economic Growth: A Cross-Country Comparison of Banks, Markets, and Development (Eds) A. Demirgüç-Kunt and R. Levine, MIT Press, Cambridge, MA, pp. $81-140$.

Diamond, D. W. (1984) Financial intermediation and delegated monitoring, The Review of Economic Studies, 51, 393-414.

Dickey, D. A. and Fuller, W. A. (1979) Distribution of the estimators for autoregressive time series with a unit root, Journal of the American Statistical Association, 74, 427-31.

${ }^{6}$ We obtained the deficit data from the International Financial Statistics (IFS) Online Service of the International Monetary Fund. 
Engle, R. F. and Granger, C. W. J. (1987) Co-integration and error correction: representation, estimation and testing, Econometrica, 55, 251-76.

Ergungor, O. E. (2004) Market- vs. bank-based financial systems: do rights and regulations really matter?, Journal of Banking \& Finance, 28, 2869-87.

Fackler, J. S. (1990) Federal credit, private credit, and economic activity, Journal of Money, Credit and Banking, 22, 444-64.

Granger, C. W. J. (1969) Investigating causal relations by econometric models and cross-spectral methods, Econometrica, 37, 424-38.

Gunther, J. W., Lown, C. S. and Robinson, K. J. (1995) Bank credit and economic activity: evidence from the Texas banking decline, Journal of Financial Services Research, 9, 31-48.

Gunther, J. W. and Moore, R. R. (1993) The long-run relationship between bank capital and lending, Financial Industry Studies, Federal Reserve Bank of Dallas, 3, 1-16.

Holmstrom, B. and Tirole, J. (1997) Financial intermediation, loanable funds, and the real sector, The Quarterly Journal of Economics, 112, 663-91.

Jeong, W., Kymn, K. O. and Kymn, C. J. (2003) The longrun interdependence of bank-health, investmentoriented bank loans, and economic performance: a time-series analysis, The Quarterly Review of Economics and Finance, 43, 11-30.

Johansen, S. (1991) Estimation and hypothesis testing of cointegration vectors in Gaussian vector autoregressive models, Econometrica, 59, 1551-80.

Johansen, S. (1995) Likelihood-based inference in cointegrated vector autoregressive models, Oxford University Press, Oxford.
Kwiatkowski, D., Phillips, P. C. B., Schmidt, P. and Shin, Y. (1992) Testing the null hypothesis of stationarity against the alternative of a unit root, Journal of Econometrics, 54, 159-78.

Levine, R. (2005) Finance and growth: theory and evidence, in Handbook of Economic Growth (Eds) P. Aghion and S. Durlauf, Elsevier Science, The Netherlands, pp. 865-934.

Lown, C. S. (1988) The credit-output link vs. the moneyoutput link: new evidence, Economic Review, Federal Reserve Bank of Dallas, November, 1-10.

Lown, C. S. (1990) Banking and the economy: What are the facts? Economic Review, Federal Reserve Bank of Dallas, September, 1-14.

Phillips, P. C. B. and Perron, P. (1988) Testing for a unit root in time series regression, Biometrika, 75, 335-46.

Quantitative Micro Software (2002) EViews 4 User's guide.

Rousseau, P. L. and Wachtel, P. (1998) Financial intermediation and economic performance: historical evidence from five industrialized countries, Journal of Money, Credit and Banking, 30, 657-78.

Shan, J. (2005) Does financial development 'lead'economic growth? A vector auto-regression appraisal, Applied Economics, 37, 1353-67.

Suzuki, T. (2004) Credit channel of monetary policy in Japan: resolving the supply versus demand puzzle, Applied Economics, 36, 2385-96.

Thießen, U. (2005) Banking crises, regulation, and growth: the case of Russia, Applied Economics, 37, 2191-203.

Thornton, D. L. (1994) Financial innovation, deregulation and the 'Credit view' of monetary policy, Federal Reserve Bank of St. Louis Review 76, 31-49.

Williamson, S. D. (1987) Financial intermediation, business failures, and real business cycles, Journal of Political Economy, 95, 1196-216. 